\title{
Optimisation of photovoltaic and battery systems from the prosumer-oriented total cost of ownership perspective
}

\author{
Kai Kappner ${ }^{*}$ (D), Peter Letmathe and Philipp Weidinger
}

\begin{abstract}
Background: In the context of the German energy transition, the number of domestic households covering part of their electricity consumption from their own photovoltaic system is constantly increasing. Some even use battery storage systems to store excess power for later use, which increases the degree of self-sufficiency and, according to the providers of such systems, should yield financial advantages for the so-called prosumer.

Methods: We used the Prosumer-Oriented Total Cost of Ownership method to analyse the financial possibilities for prosumers under German market conditions, and thus determined the economically optimal solution for different domestic household sizes. In order to obtain realistic results, we applied real data covering the weather (relevant for the generation of electricity), consumption patterns, investment and operating costs, prices and revenues. If behavioural aspects are set aside and pre-requirements (e.g. sufficient roof space) are met, our model provides guidance for investors and policy-makers alike.

Results and conclusions: Our research shows that it is financially advantageous for all household sizes to operate the largest photovoltaic system possible for them (up to $10 \mathrm{~kW}$ ). By contrast, our results show that the investment in a battery storage system does not pay off even when government subsidies are taken into account. Regardless of the size of the selected battery storage system and all other influencing variables, the financial advantages of such a system do not materialise, although a battery storage system does substantially increase the self-sufficiency rate.
\end{abstract}

Keywords: Total cost of ownership, PV system, Battery energy storage system, Prosumer, Discrete optimisation, Energy transition

\section{Background Introduction}

The transition of the German energy system is a huge challenge for policy-makers and is absolutely necessary if emissions are to be reduced. However, this transition cannot be successful unless a broad participation of energy producers and energy consumers is achieved and their efforts are well coordinated and aligned with each other [1-3].

In 2009, the European Parliament already enacted the goal of a $20 \%$ improvement in energy efficiency by 2020 compared to 1990 [4]. It also "endorsed a mandatory target of a $20 \%$ share of energy from renewable sources in overall

* Correspondence: kappner@controlling.rwth-aachen.de

School of Business and Economics, RWTH Aachen University, Templergraben 64, 52062 Aachen, Germany community energy consumption by 2020 and a mandatory $10 \%$ minimum target to be achieved by all Member States for the share of biofuels in transport petrol and diesel consumption by 2020, to be introduced in a cost-effective way" [4]. For a long time now, Germany has been regarded as the leader of the energy transition. Even the German expression "Energiewende" has been adopted worldwide. In 2010, the German Federal Ministry for the Environment, Nature Conservation and Nuclear Safety focused on a more decentralised renewable energy generation and consumption with a better integration of renewable energy systems (RES) in the energy mix.

To facilitate this, the development of the electricity grid was identified as a mandatory factor-both in terms of capacity (installing the new lines needed as well as adapting already installed ones to changed needs) and quality (such as 
making the grid more efficient by avoiding losses). These efforts should be accompanied by an expansion of energy storage systems [5]. Hence, the German government has involved citizens of Germany in large incentive programmes. In 2010, photovoltaics (PV) only generated 9\% of the electrical energy but incurred $40 \%$ of the incentive costs [5]. Although the European Commission had determined PV as a leading-edge technology with high potential for exports in a very competitive global market [6], electricity generation with PV had only reached $6.1 \%$ in Germany by 2017 [7]. Following the IPCC Special Report Global Warming on 1.5C, PV solutions for prosumers with increasing self-sufficiency will become more important [8]. Despite these high ambitions and even though some authors attest the German energy transition as "the core of a comprehensive strategy to redirect Germany onto a future-oriented and sustainable path" [9], Germany will not only fail its own climate goals but also its European obligations [10]. In fact, it is very likely that Germany will also fail to meet the target set in the coalition agreement of generating $65 \%$ of its energy from RES by 2030 [11]. Even though the transition of the German energy system in general is not the focus of this study, the change towards a bottom-up market structure involving prosumers will accelerate the energy transition on the whole [1].

The share of decentralised generated electricity, often at the locations where it is consumed, will increase. These decentralised generation entities, in particular prosumers, will have to be integrated into the future grid in order to support the system's stability and efficiency [12]. Figure 1 illustrates the current top-down model of the electricity supply on the left side, while new participants and multi-level exchange structures will arise in the future (right side). The European Parliament supports the goals of lowering the connection costs and ensuring an equal treatment of consumers in rural and city areas [4]. Since energy generation in a bottom-up market model is a ground-breaking change, the new situation for consumers and prosumers needs to be evaluated financially [14]. However, not only will the electricity market change because of this new model, but direct current (DC) generation (PV), the need for energy storage and new connection technologies will also fundamentally affect the electricity market.

In this paper we examine the disruptive and new market player- "the prosumer" [13] — and evaluate the different scenarios of production, storage and self-consumption with a focus on the financial consequences and based on real data.

The changes to the German energy system are a good example of a politically induced technological change process [15]. To get its citizens involved, the German government provided an incentive for the generation of electrical energy from privately owned PV panels with up to $0.507 €$ per feedin kilowatt hour as regulated by the Erneuerbare-EnergienGesetz (EEG-Renewable Energy Law) [16, 17]. In addition, the government also introduced incentives for local storage systems, such as reduced interest rates for loans when investing in battery systems, to ensure a reliable energy source and rules for self-consumption to relieve the grid [5]. In this vein, we also take into account different discount rates for

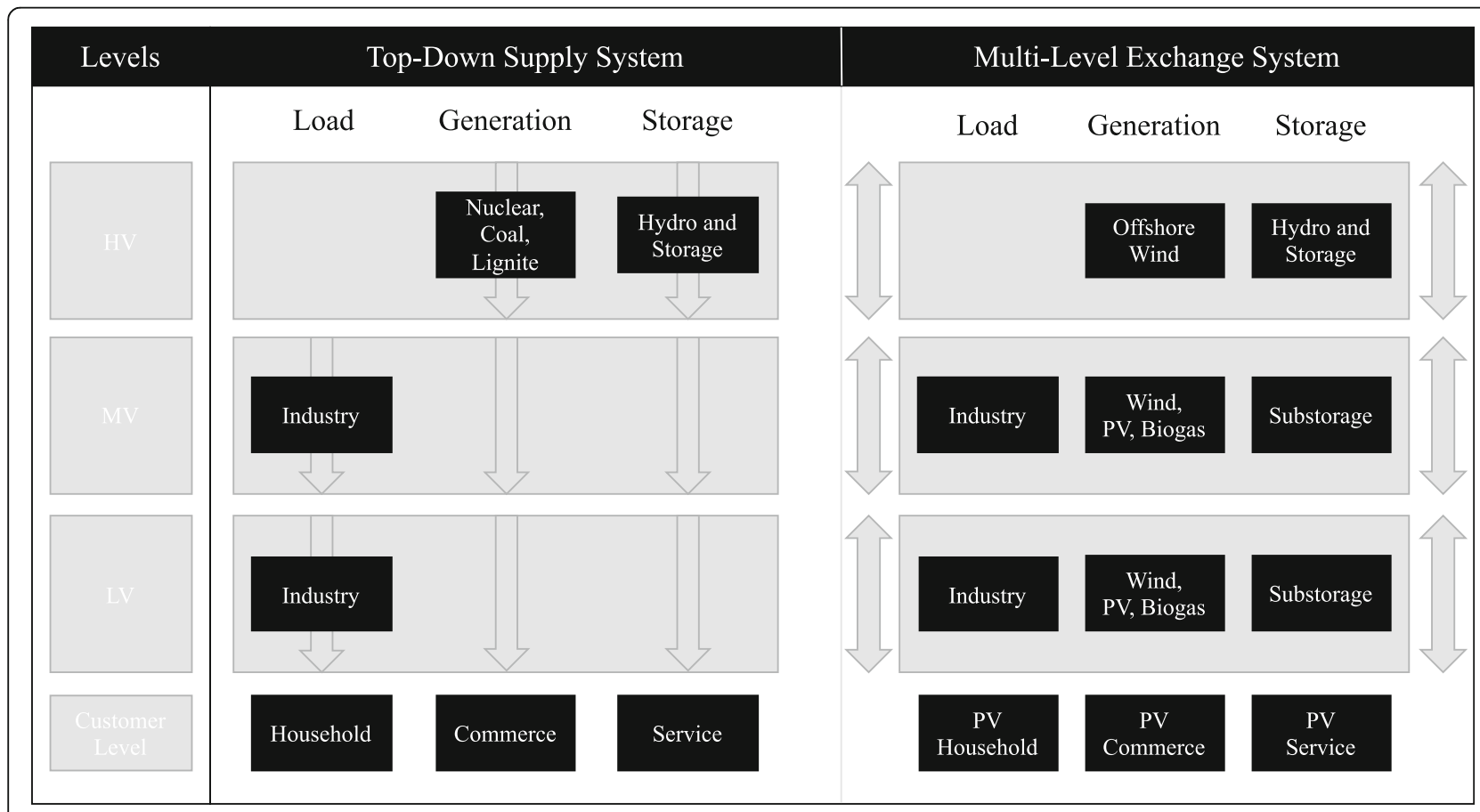

Fig. 1 Transformation of the electricity system [13] 
investments in the generation of electricity from renewable resources $[18,19]$. These incentives for the generation of local electricity, storage and self-consumption support a bottom-up model for the energy transition and create the need for integrated intelligent management systems and customer obligation. Thereby, the reward for self-consumption is implicit in its nature. Consumers who consume their selfproduced electricity do not have to buy it from the electricity supplier. Hence, the consumer saves $0.29 €$ per kilowatt hour, which is higher than the remuneration of the net feedin tariff of $0.12 € / \mathrm{kWh}$. This leads to an overall saving through self-consumption of $0.17 \quad € / \mathrm{kWh} \quad(0.29-0.12$ $€ / \mathrm{kWh}$ ). Figure 2 shows those areas which require new management structures [14]. These new structures could also be implemented on the low-voltage level. Prosumers can offer (part of) the needed storage and generation capacities. By relocating the generation of electricity, a relocation of the corresponding electricity services is also required. Thus, the need for new electricity services will increase with a growing share of RES, whereas the conventional generators who delivered most of the energy in the past will disappear. Thus, the decentralised generation entities have to be integrated into the energy system. Figure 2 indicates which areas of the electricity grid are affected and, in particular, which special services are required for relocation towards decentralised and small entities, such as prosumers.

Due to governmental subsidies and as Fig. 3 shows, installed PV power rose dramatically from 2000 to 2016 [20] even though installing a PV system comes with high initial costs [14]. These costs can mainly be attributed to investment costs as planning and approval costs are very low in Germany. Subsidised PV systems generate revenues over time. Even when incentives, such as guaranteed feed-in remunerations, are lower, investing in PV panels can still be attractive due to the opportunity to consume self-produced electricity, meaning that electricity does not have to be purchased with an average price of $0.2916 € / \mathrm{kWh}$ (based on $3500 \mathrm{kWh} /$ year consumption [21, 22]).

Most of the savings of self-produced electrical energy result from the elimination of costs for distribution, levies and taxes. These are taxes (55\%) and network charges (25.7\%) and also surcharges for purchase and distribution (19.3\%) [21]. Furthermore, fees for grid stability and ancillary services can be avoided [23].

The goal of this paper is to determine the financial feasibility of privately owned PV-based electricity generation under the specific market conditions in Germany and by considering the capacities of PV systems. "Specific market conditions" refers to electricity prices and, in particular, to feed-in tariffs and regulations. Regarding household electricity prices, Germany's are the highest in Europe [24]. Regarding the feed-in tariffs and regulations, there are numerous variations in Europe [25]. Germany has a relatively high feed-in tariff, which is guaranteed over a time period of 20 years for private investors in PV panels. We worked with real data (so-called H0 standard load profile) for an average German household and the data set of global radiation for Aachen (a city in western Germany) to calculate PV-based electricity production. In terms of PV system attractiveness Aachen is similar to many other cities in Germany because of its latitude and because of global radiation it is in the medium range within Germany. Furthermore, we calculated the economic feasibility of storage systems by taking the subsidised German feedin tariff, market prices for battery energy storage systems (BES systems) as well as for PV panels, and an average electricity price of $0.29 € / \mathrm{kWh}$ into account. Since the electricity price is largely made up of taxes and levies, the variable share of the generation cost per kilowatt hour is relatively small. Following that, the variances for the average electricity price is low.

With different scenario analyses, we computed the hourly electricity production, self-consumption, battery charge

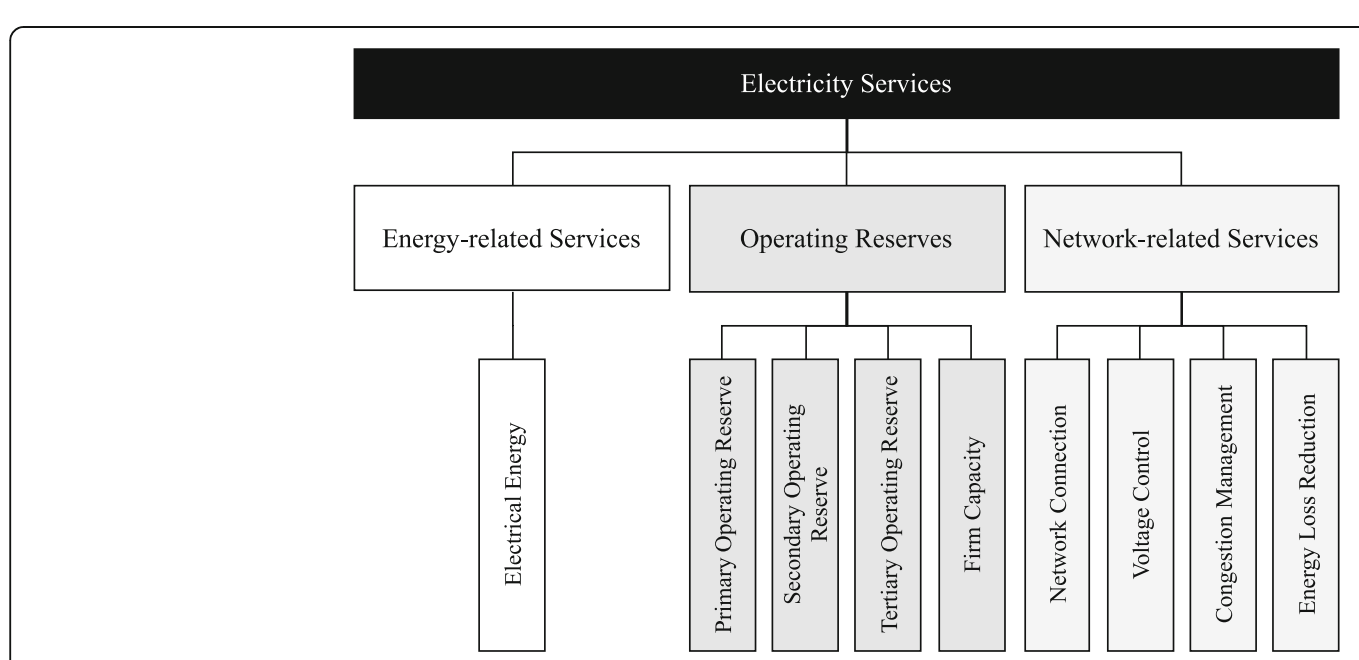

Fig. 2 Electricity services [14] 
Installed PV Power in Germany from Year 2000 to 2016

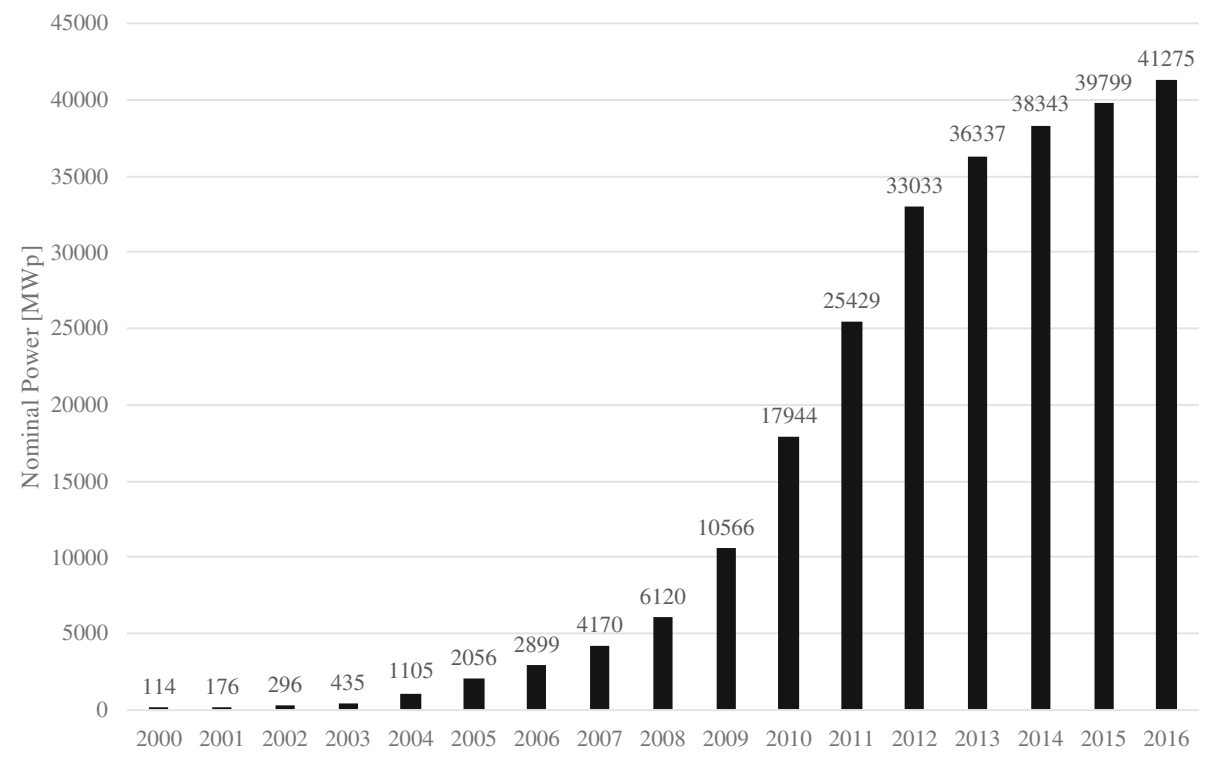

Fig. 3 Installed PV power in Germany from 2000 to 2016

status and grid balance. Based on these values we determined the relevant cash flows. The net present value (NPV) and the resulting annuity were calculated using a total cost of ownership (TCO) model for 20 years, covering the typical usage period for PV panels in Germany. As mentioned, we used the $\mathrm{HO}$ profile as our underlying consumption pattern of private households. Although it can be stated that a smart use of electricity within the household can increase the selfsufficiency rate or the efficiency of energy use [26], behavioural studies show that consumers do not always react rationally [27-29]. Hence, the H0 profile aims to realistically reflect current consumption patterns.

\section{Literature review}

Existing literature has already analysed BES for private entities. Owing to the widespread challenges that the so-called prosumer model generates, the structured investigation of the different model options and the analysis of their economic feasibility appear to be necessary. To calculate the profitability of an integrated PV-BES system, one should consider as many aspects as possible. Table 1 includes an overview of the relevant literature which has analysed the different perspectives of the prosumer model for private customers. We have also analysed papers which consider PVand PV-BES-systems from a financial perspective. Tables 1 and 2 show the methods and the assumptions made to generate viable results. In Table 2, we only list such papers which provide explicit values. However, no comprehensive approaches have been implemented yet. Therefore, in this article we go beyond the currently available literature and combine a PV and a BES, while also taking into account technical restrictions and evaluating the system from a financial point of view by applying a prosumer-oriented TCO model $\left(\mathrm{TCO}_{\mathrm{P}}\right)$.

According to Tables 1 and 2, in the existing literature there are various investigations in the fields of PV and BES and their financial aspects. However, some work is limited to the consideration of PV systems only [31, 33, 37]. Other research which also considers PV and BES models focusses on countries and markets outside Germany, such as Australia [30], Italy [32, 34], Sweden [44] and UK [42]. Moreover, previous studies usually only consider one single household size [36] or assume (partially) already installed systems [39]. Many studies work with linearised prices for assets and services, whereby such a procedure does not reflect exactly the conditions for a potential prosumer.

In addition to models from scientific studies, there is also software available which can be used to calculate the economic viability of various clean energy projects, such as RETScreen [45], which is produced by the Canadian government. There are some scientific publications that use this software for their investigations. However, a deeper analysis of this tool is not possible, since publications from recent years that disclose the concrete calculations of the underlying model are not available. Based on the existing research, our contribution is the following: In our model, we provide an improved granularity regarding input data such as generation and consumption profiles, and we use exact prices for assets and their financing as well. Furthermore, we have adapted our model to the regulatory conditions in Germany, and we calculate the annuities, which a prosumer can easily compare with his or her monthly payments. 
Table 1 Prosumer literature review

\begin{tabular}{|c|c|c|c|c|c|c|c|c|}
\hline \multirow[t]{2}{*}{ \# } & \multirow[t]{2}{*}{ References } & \multicolumn{2}{|c|}{$\begin{array}{l}\text { Business } \\
\text { administration }\end{array}$} & \multirow[t]{2}{*}{ Economic } & \multirow[t]{2}{*}{ Technical } & \multirow[t]{2}{*}{ PV } & \multirow[t]{2}{*}{ BES } & \multirow[t]{2}{*}{ Description } \\
\hline & & Other & TCO & & & & & \\
\hline 1 & Akter et al. [30] & $x$ & & & $x$ & $x$ & $x$ & $\begin{array}{l}\text { - Solar photovoltaic units and battery energy storage systems } \\
\text { - Levelised cost of energy along with reductions in carbon dioxide } \\
\text { emissions and grid independency } \\
\text { - In Australia }\end{array}$ \\
\hline 2 & Bertolini et al. [31] & $x$ & $x$ & & & $x$ & & - Impact of a PV system for micro-grids \\
\hline 3 & Bortolini et al. [32] & $x$ & & & & $x$ & $x$ & - Economic model for grid-connected PV and BES system in Italy \\
\hline 4 & $\begin{array}{l}\text { Comello and } \\
\text { Reichelstein [33] }\end{array}$ & $x$ & & & & $x$ & & $\begin{array}{l}\text { - Economic efficiency of PV in the U.S. } \\
\text { - Remuneration system }\end{array}$ \\
\hline 5 & Cucchiella et al. [34] & $x$ & & & & $x$ & $x$ & $\begin{array}{l}\text { - Profitability of PV systems } \\
\text { - profitability of energy storage in a mature market in Italy }\end{array}$ \\
\hline 6 & $\begin{array}{l}\text { Kamankesh and } \\
\text { Agelidis [35] }\end{array}$ & $x$ & & $x$ & & $x$ & & $\begin{array}{l}\text { - Optimising the management of the grid with high share of RES and } \\
\text { V2G }\end{array}$ \\
\hline 7 & Kaschub et al. [36] & $x$ & & & & $x$ & $x$ & $\begin{array}{l}\text { - Developments of battery storage technology with PV } \\
\text { - Generation mix of utilities, use of the distribution grid, and electricity } \\
\text { price }\end{array}$ \\
\hline 8 & Klise et al. [37] & $x$ & $x$ & & & $x$ & & $\begin{array}{l}\text { - TCO for PV systems in the U.S. } \\
\text { • Discounted cash flow }\end{array}$ \\
\hline 9 & McDowall [38] & & & & $x$ & $x$ & $x$ & - Significance of BES for the autarchy of micro-grids \\
\hline 10 & Naumann et al. [39] & $x$ & & & $x$ & & $x$ & $\begin{array}{l}\text { - Costs and revenues for BES } \\
\text { - Techno-economic model for revenues }\end{array}$ \\
\hline 11 & $\begin{array}{l}\text { Rosen and Madlener } \\
{[40]}\end{array}$ & & & $x$ & & & & $\begin{array}{l}\text { - Changes in market regulations } \\
\text { - Enable trading of energy for prosumers }\end{array}$ \\
\hline 12 & Rylatt et al. [41] & & & $x$ & $x$ & & & $\begin{array}{l}\text { - Market model } \\
\text { - Prosumer is embedded in an aggregator structure }\end{array}$ \\
\hline 13 & Uddin et al. [42] & $x$ & & & & $x$ & $x$ & $\begin{array}{l}\text { - Photovoltaic systems integrated with lithium-ion BES } \\
\text { - In UK }\end{array}$ \\
\hline 14 & Vosoogh et al. [43] & $x$ & & $x$ & $x$ & $x$ & $x$ & - Optimising the energy flow in a microgrid \\
\hline 15 & Zhang et al. [44] & $x$ & & & & $x$ & $x$ & $\begin{array}{l}\text { - Three different types of BES } \\
\text { - In Sweden }\end{array}$ \\
\hline
\end{tabular}

Table 2 Data analysis from the literature

\begin{tabular}{|c|c|c|c|c|c|c|c|c|}
\hline \# & Author & $\begin{array}{l}\text { Interest rate per } \\
\text { year (\%) }\end{array}$ & $\begin{array}{l}\text { Opportunity costs of } \\
\text { capital (\%) }\end{array}$ & $\begin{array}{l}\text { Inflation per } \\
\text { year (\%) }\end{array}$ & $\begin{array}{l}\text { Electricity price } \\
\text { (ct/kWh) }\end{array}$ & $\begin{array}{l}\text { Feed-in } \\
\text { remuneration (ct/ } \\
\mathrm{kWh} \text { ) }\end{array}$ & $\begin{array}{l}\text { Lifetime PV } \\
\text { (years) }\end{array}$ & $\begin{array}{l}\text { Lifetime BES } \\
\text { (years) }\end{array}$ \\
\hline 1 & Akter et al. [30] & 4 & - & - & 22 & - & 25 & 10 \\
\hline 2 & Bertolini et al. [31] & 5 & & & 16 & & 20 and 25 & - \\
\hline 3 & Bortolini et al. [32] & - & 5 & 3 & 20 & 4 & 25 & 25 \\
\hline 4 & $\begin{array}{l}\text { Comello and } \\
\text { Reichelstein [33] }\end{array}$ & 7.5 & & & $10-13.5$ & $11-28$ & 30 & - \\
\hline 5 & $\begin{array}{l}\text { Cucchiella et al. } \\
\text { [34] }\end{array}$ & 3 & 5 & 2 & 20 & 19 & 20 & 20 \\
\hline 6 & Kaschub et al. [36] & 1 & - & 2 & 29.5 & 3.5 & 20 & 20 \\
\hline 7 & Klise et al. [37] & & & & 11.1 & & 25 & - \\
\hline 8 & Naumann et al. [39] & 4 & - & 2 & 30 & 12.56 & 20 & 12.5 \\
\hline 9 & Uddin et al. [42] & - & - & - & - & - & - & 5 \\
\hline 10 & Zhang et al. [44] & - & - & - & - & - & 25 & 25 \\
\hline
\end{tabular}


To do this, the application of the $\mathrm{TCO}_{\mathrm{P}}$ concept is very suitable. The TCO method analyses activities and related cash flows within an investment's useful lifetime [46]. It has a broad scope and also includes pre-purchase costs, for instance [47, 48]. This comprehensive approach distinguishes the TCO from other comparable methods [49].

To investigate a long-term investment such as in a PVBES-system, the TCO concept is particularly suitable because it is designed to be activity-based and it informs the entityin this case the prosumer who owns the PV-BES-systemabout the economics of past, current and future decisions $[47,50]$. Furthermore, the TCO concept is logical and easy to understand, especially as it focuses on the total cost of an investment [46]. TCO shifts the focus from the purchase cost to the total cost and is therefore more suitable for making informed decisions [51]. This means that TCO is not only a purchasing tool but also a philosophy [47] which helps a purchaser to understand the real costs of buying a particular good from a particular supplier [46, 47]. In this case, the paper provides objective information for those customers who want to become prosumers by investing in a PV and/or a BES-system. Furthermore, the TCO concept allows the user to understand, analyse and manage the financial consequences of purchased items in a progressive and systematic way [46]. Specifically, the TCO method allows the user to consider such elements as order placement, research and qualification of suppliers, transportation, receiving, inspection, rejection, replacement, downtime caused by failure, and disposal costs $[47,52]$. Thus, the TCO concept displays more than just purchase prices, by considering the costs of the entire product-life, such as those related to service, quality, delivery, administration, communication, failure, maintenance and so on $[52,53]$. Beyond that, the TCO approach takes into account the transaction costs [51]. However, as the TCO concept requires detailed accounting and costing data, the lack of readily available data might be a limitation [47]. Furthermore, the "TCO concept requires firms [or entities] to consider those activities that are causing them to incur costs. By analysing flows and activities within each process, a firm can identify which activities add value, and which do not" [46]. Hence, the user of $\mathrm{TCO}_{\mathrm{P}}$ is the prosumer conceptualising the system $\mathrm{s} /$ he is willing to invest in [54]. As our TCO model considers not only costs but also revenues from a prosumer's perspective, we make a contribution by extending traditional consumer-oriented TCO models towards a prosumer-oriented TCO model. To address the identified research gap by applying the $\mathrm{TCO}_{\mathrm{P}}$ concept, this paper raises the following research questions:

RQ1: Which adjustments need to be added to existing TCO models in combination with PV-BES-systems based on detailed real-world data sets and how can the $\mathrm{TCO}_{\mathrm{P}}$ be calculated for different PV systems in combination with BES systems under different usage scenarios?
RQ2: What is the most cost-effective option for a PVBES-system from the user perspective under consideration of German market conditions and how are the results influenced by German legislation for feeding-in electricity from renewable energy sources?

\section{Contribution}

The article makes a contribution by providing a $\mathrm{TCO}_{\mathrm{P}}$ model based on the existing literature, which closes the identified research gap, by providing a comprehensive consumeroriented calculation of a PV-BES-system with real data and different realistic household sizes. This article positions the prosumer as the owner of the system at the centre of our analysis. The calculation provides a realistic outcome of the aspects of using self-produced electricity, storage and connection to the grid, presenting the opportunity to feed-in and use electrical energy. We developed a $\mathrm{TCO}_{\mathrm{P}}$ model for a 20-year lifetime period under realistic usage conditions with the possibility to analyse changes in the discount rate, inflation, increasing energy efficiency, etc. Based on this, we applied the model to real market data. Thus, we obtained results for different constellations of household size, PV system capacities and BES capacities. Using discrete optimisation, we were able to determine the financially best constellation for different household sizes. We also relate the calculations' results to the corresponding self-sufficiency rates. Although our analyses focus on the German energy market, the development of the extended $\mathrm{TCO}_{\mathrm{P}}$ methodology can also be adapted to other market conditions or restrictions. Answering the questions above contribute to a more independent and holistic economic evaluation of participating in the energy transition in Germany as a prosumer. Moreover, the results help to identify relevant improvement potential for governmental policy-makers when setting incentives and for producers when designing prosumeroriented products.

This article is structured as follows: The "Methods" section discusses the methodology and explains the data set with its core components and restrictions. The "Results and discussions" section discusses the results of baseline scenarios under German market conditions. Furthermore, we validate the methodology and perform various scenario and sensitivity analyses in order to show the impacts of changes with the variables used. The "Conclusions and policy implications" section concludes with the key results, a short discussion of the limitations and a discussion of future research potential.

\section{Methods}

Sample

Our analyses focus on domestic households-detached houses with one family per house in the German city of Aachen with roof surfaces that are suitable for the installation of a PV system. We considered different household sizes, ranging from one to four persons and determined the 
financially optimal combination of a PV system and a BES. We also accounted for the investment in a PV system without any BES as well as the waiver of both. Different sizes of a PV system up to an installed capacity of $10 \mathrm{~kW}_{\mathrm{p}}$ were included in the analyses. Larger systems are typically too large for the roof of a detached house due to the area needed. Furthermore, only the private operators of plants up to this size benefit from the legally guaranteed fixed feed-in tariff.

In our study, households were equipped with various battery storage devices available for home use. Exact values and data are provided in the following sections. The data structure and calculations used in this study are illustrated in Fig. 5.

\section{Instrument}

Our $\mathrm{TCO}_{\mathrm{P}}$ calculations are based on a comprehensive model including all cash flows related to electricity consumption, generation and storage using a dynamic investment appraisal method-the net present value (NPV) method. The basic structure of the calculation of the annuity calculation based on an investment's NPV is shown in Eq. 1.

$$
C_{\mathrm{TCO}_{\mathrm{P}}}=C_{\mathrm{NPV}} \frac{(1+i)^{t} * i}{(1+i)^{t}-1}
$$

$C_{\mathrm{TCO}}$ characterises the annual prosumer-oriented total cost of ownership, hereinafter also referred to as annuity. $C_{\mathrm{NPV}}$ is the net present value, $t$ is the index for the period during the period under review and $i$ is the rate, with which all payments are discounted. We considered the costs on an annual basis, as costs per year are usually calculated in the private energy sector. For the general structure of the $\mathrm{TCO}_{\mathrm{P}}$ model, please refer to Fig. 4.

Our model was implemented using Visual Basics for Applications (VBA).

\section{Net present value}

The net present value $C_{\mathrm{NPV}}$ was determined by adding up all observed cash flows, which are discounted on an accrual basis, as shown in Eq. (2).

$$
C_{\mathrm{NPV}}=C_{\text {Capex }}+\sum_{t=1}^{T} \frac{C_{\text {Opex }, t}}{(1+i)^{t}}
$$

$C_{\text {Capex }}$ is the capital expenditure, $C_{\text {Opex }, t}$ is the operational expenditure in period $t, T$ is the whole period under review and $i$ is the discount rate. The elements of $C_{\text {Capex }}$ and $C_{\text {Opex, } t}$ are described in the following sections. The NPV is calculated with different parameters: internal and external ones. The interdependencies are illustrated in Fig. 5.

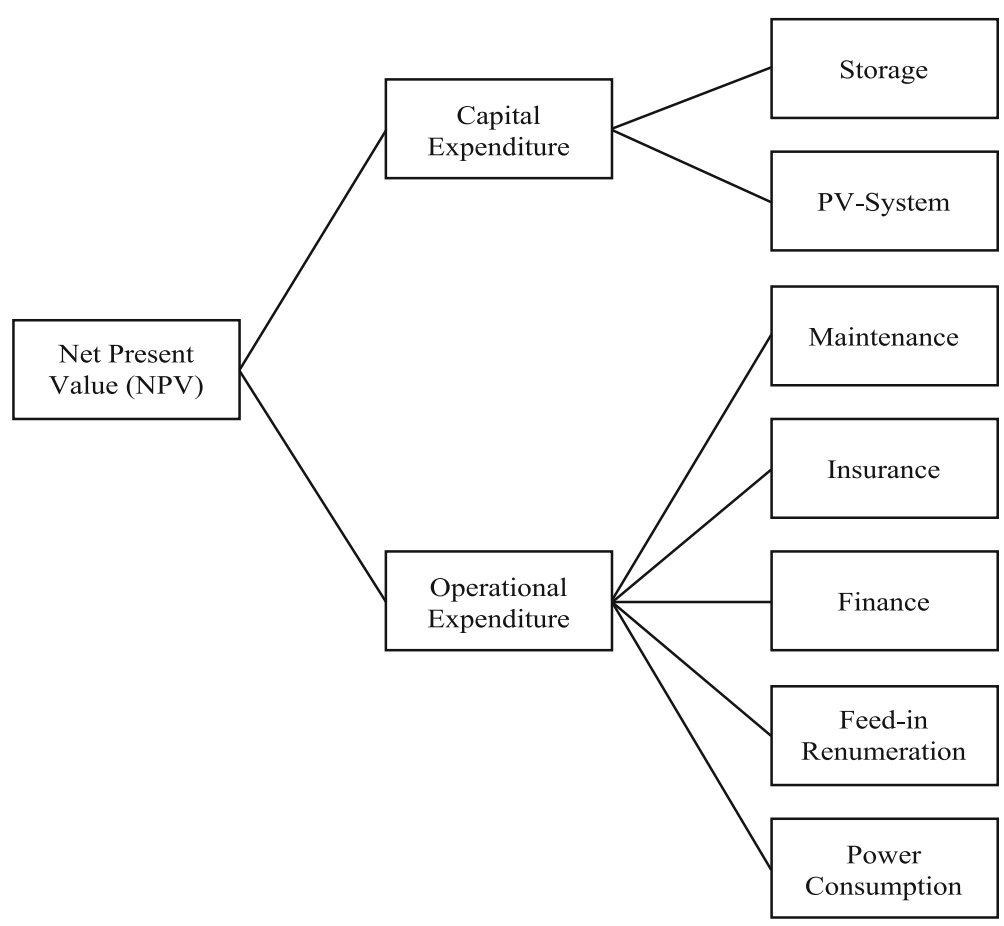

Fig. 4 Structure of $\mathrm{TCO}_{\mathrm{p}}$ model 


\section{Capital expenditure}

The capital expenditure for the prosumer consists of two main components which have to be provided at the beginning of use. The first expenditure is for the PV panels, which are mounted on the roof of the house and generate electricity after installation from the available solar radiation. Moreover, the brackets that are used to position the panels on the roof, and the power electronics required for using the panel incur additional capital expenditure. Additionally, the one-time installation of the system should be taken into account as it entails a considerable part of the expenses.

The second capital expenditure that has to be considered is for the battery storage. The battery storage can be purchased together with the PV system as a package or separately. For feed-in and current discharge, power electronics are needed as well. This battery storage can be seen as a separate investment, since it is optional and can be installed in addition to an existing PV system or simultaneously with a new PV system. It does not make sense to install a battery storage without a PV system because there is no financial advantage of feeding-in electricity that has been withdrawn from the grid before and it is not compensated by the EEG either. Another asset that has to be installed is the grid connection. However, all costs covering this investment have to be borne by the local distribution system operator (DSO). In
Germany, the local DSO is obligated by law to set up a grid connection for any renewable energy source [55]. The operator of the system only has to request that the necessary devices are set up.

Since we do not consider a 100\% isolated system, a complete omission of an investment is also possible. In this case there is no capital expenditure, of course. Thus, the "traditional" consumer with a normal grid connection suitable for consumption can be seen as our base case. The Kreditanstalt für Wiederaufbau (KfW) bank offers special loans and federal subsidies for BES $[56,57]$ to finance the listed expenditures.

\section{Operating expenditure and revenue}

The operating expenditures are manifold. It is a fact that every consumer/prosumer has to pay for electricity that is drawn from the grid. As a private customer, a fixed price per kilowatt hour is paid to the respective electricity supplier. The amount of electricity drawn from the grid depends on various factors. Without PV panels and battery storage, all power consumption is drawn from the grid. If a PV system exists, electricity is only drawn if the current consumption in the household exceeds the current electricity generation of the PV system. If a battery storage is added, the purchase of

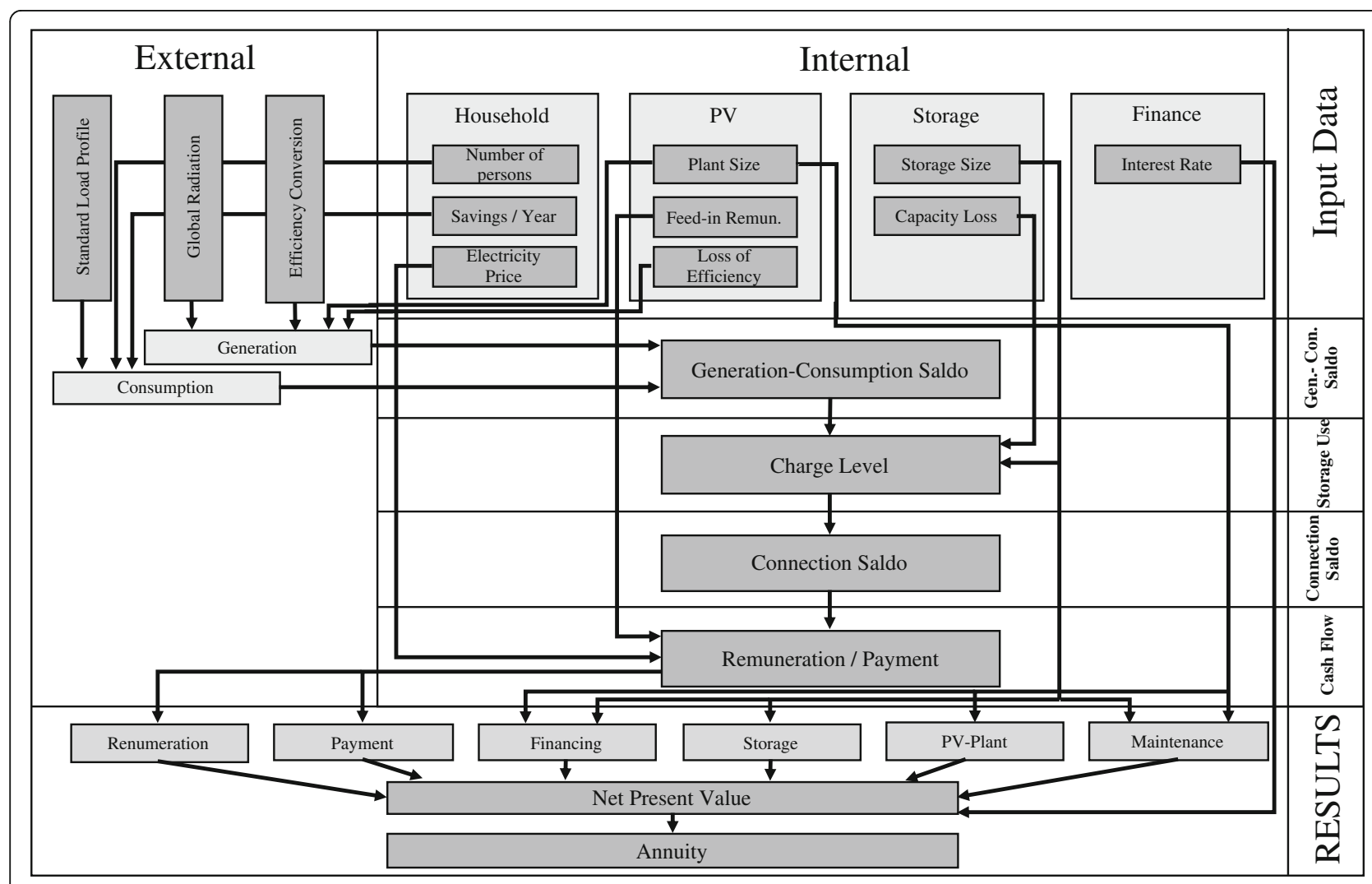

Fig. 5 Data structure 
electricity from the grid is limited to situations where both the consumption exceeds the generation and the battery storage is empty and can no longer provide electrical power.

This is (partially) offset by payments for electricity fed into the grid. Just like the price for the electricity consumed, the feed-in tariff is fixed at a certain amount per kilowatt hour. The payment is made by the grid operator and is guaranteed by the EEG. If no storage is available, electricity is fed into the grid as soon as the electricity generated by the PV system exceeds consumption. In combination with a BES, electricity is fed-in when both production exceeds consumption and the battery storage unit is fully charged and cannot store any more electrical energy.

Two other cost categories have to be considered. If a prosumer invests in both a PV system and a BES, then both have to be maintained and the PV panels are often insured against, for instance, damages caused by hail. Regardless of the operation, but still during the use phase, there are cash flows caused by financing the PV system and the battery storage. The payments include the repayment of the loan and the corresponding interest payments. The financing of the acquisition costs by means of a loan is not obligatory but it is recommended due to the aforementioned support from the KfW bank and the German Federal Government.

\section{End-of-life costs}

Our calculations do not consider end-of-life costs. Due to the fact that BES is a new technology, there is no reliable information available about potential revenues or costs associated with PV systems and battery storage systems at the end of their lifetime of 20 years. Therefore, we assume a cost-neutral disposal of the devices.

\section{Parameter values of core components Capital expenditure}

To create a basis for our calculations, we initially collected data for the German market for battery storage systems for home use. The capacity of battery storage units available on the market ranges from 2 [58] to $20 \mathrm{kWh}$ [59]. BES are offered by different companies. On the one hand, there are automobile manufacturers, such as Mercedes-Benz [59] and the electric car manufacturer Tesla [60]. Furthermore, electronics manufacturers offer battery storage systems for household use. For example, copies of LG [61] or Samsung [62] are available. On the other hand, manufacturers such as sonnen $\mathrm{GmbH}$ [63] specialise exclusively in products related to private solar power.

We then manually collected data on the products of the various suppliers according to capacity and price to obtain a comprehensive overview of the German BES market. For all suppliers, the price per kilowatt hour of storage capacity decreases as the capacity of the battery storage increases. Based on our compilation, we calculated an average price of $1250 €$ for $1 \mathrm{kWh}$ of storage capacity. This price per kilowatt hour is somewhat higher for small storage systems and slightly lower for larger systems.

The market leader in Germany is the supplier sonnen $\mathrm{GmbH}$ with its products summarised under the brand name sonnenBatterie [64]. Batteries for households are on offer in all relevant sizes. Our market analysis shows that these products represent the market very well in terms of the relationship between the price and the performance offered. Based on our maxim of calculating with concrete, real market data in all areas, we chose models from their product portfolio for our research. Table 3 shows the different models used in this study [63]. These products are fully representative of the market both in terms of price to capacity ratio and in terms of the sizes on offer.

The guaranteed minimum lifetime of the selected battery storage is 10 years. However, this does not mean that the battery memory is no longer functional after this period of time. Previous studies assume a total lifespan of 20 years or more [32, 34, 36, 44]. This corresponds to the period covered by our study. Thus, it would be worth using a battery storage during this observation period. In order to take the ageing of the battery storage into account, we tested our results for influences of an annual decrease in storage capacity (see Case 3 - Capacity Loss of the BES System).

Prices for PV systems have fallen sharply over the past 10 years. High production figures have led to significant economies of scale, and the competitive pressure on the market has become increasingly powerful. In recent years, however, the decline in prices has slowed down [65]. Based on past data, we assume an average price of $1168 €$ per $\mathrm{kW}_{\mathrm{p}}$ of installed capacity. This includes the cost of installation and wiring. The size of the installed system cannot be chosen freely but depends on the number of installed panels, which is an integer number. As a representative example, we chose the panels of the German manufacturer Viessmann [66]. This company is one of the leading manufacturers of solar panels in Europe, and especially in Germany [67]. Table 4 shows the different variations of installed capacity used in this study. The listed panels are fully representative of the market in terms of technical parameters and the ratio of price and nominal capacity.

The guaranteed lifetime of the chosen PV panels is 25 years. The manufacturer guarantees at least $80 \%$ of the original nominal capacity for the first 25 years [66]. In

Table 3 Selected BES models

\begin{tabular}{lll}
\hline Capacity $(\mathrm{kWh})$ & Brand & Price (incl. VAT) \\
\hline 6 & sonnenBatterie & $8799 €$ \\
10 & sonnenBatterie & $12,799 €$ \\
16 & sonnenBatterie & $17,699 €$ \\
\hline
\end{tabular}


our study, we assumed that the PV panels are installed once and then used for the whole observation period of 20 years. This is consistent with previous studies, all of which assumed a lifetime of 20 years or longer for PV panels [30, 32, 34, 36, 39, 44]. In addition, the legally guaranteed remuneration period amounts to 20 years [68]. Losses of nominal capacity of the PV panels are taken into account by testing our results for influences of different yearly losses in efficiency (see the "Case 2efficiency losses of the PV system" section).

\section{Operating expenditures and revenues}

The expenditures for operating a prosumer system can be divided into fixed and variable costs. Fixed costs are costs for maintenance and insurance. Both values can vary depending on the data source. Some providers of systems include maintenance and/or insurance in the price. Therefore, some studies have calculated these costs as a proportion of the investment costs. However, it is usually common for maintenance and insurance to be paid annually. On the basis of various offers on the market and work from previous studies, we assumed that $100 €$ per year will be spent on maintenance and 70 $€$ per year on insurance [32, 34, 39]. For example, the functionality of a PV system and the associated electronics must be checked regularly. The variable costs result from the consumption of the electricity drawn from the grid. These are partially offset by the revenues from feeding the self-generated electricity into the grid.

To determine a representative consumption profile, we received information from the local DSO "Regionetz" [69]. This information provides a curve of the electricity consumption of a typical household in Aachen on a quarter-hourly basis. With this curve and the average annual consumption of different household sizes, the consumption values are calculated in quarter-hourly cycles over the course of a whole year. Changes in consumption quantity were taken into account in the scenario analysis discussed in the "Sensitivity analysis" section.

To calculate the electricity generated by the PV panels, we adopted an approach that provides the most realistic possible data basis. Global radiation causes the production of electricity with PV panels. This global radiation varies depending on the location and the position of the sun as well as the weather. A PV system with an installed capacity of $1 \mathrm{~kW}_{\mathrm{p}}$ at the Aachen site generates
$883.5 \mathrm{kWh}$ of electricity per year on average [70]. This value already includes efficiency losses due to temperature fluctuations, line losses and power electronics. The amount of electricity generated can vary slightly within Germany but differences in most areas within Germany are relatively low compared to other countries. The reason for this is that in Germany a large part of the global radiation is diffuse radiation. Diffuse radiation also occurs under cloudy conditions and is less dependent on the exact position of the sun [71, 72].

In order to obtain a representative generation profile, measured values for global radiation for the years 20112017 for the Aachen site [72] were used. Together with the average electricity generation, we were able to calculate annual generation profiles with an hourly resolution which we divided linearly into quarter-hour sections. This approach allows us to reach the lowest granularity possible even if we should lose a small amount of accuracy due to the unavailability of more detailed data coverage on electricity generation.

Combining both consumption and generation allows the difference between electricity generation and consumption to be calculated. A positive difference indicates that generation exceeds consumption, whereas a negative difference is indicative of the opposite. For a positive difference, the excess electricity is fed into the grid or the battery storage is charged. If the difference is negative, electricity is withdrawn from the grid or from the battery storage.

Without any battery storage, no further decision is required. However, if there is a battery storage, the prosumer has to decide between feeding-in and charging or, rather, between withdrawing from the grid and withdrawing from the battery storage. As the feed-in remuneration is significantly lower than the price of electricity from the grid, the financially best option is always to charge or to discharge the battery storage until it is fully loaded or fully discharged before feeding-in or withdrawing, respectively.

In accordance with this strategy, we map a curve showing the charging level of the battery storage and a data series of feeding-in and withdrawal activities. Those streams of electricity, both the fed-in and the withdrawn electricity, can be assessed financially. Charging and discharging the battery are not linked to any cash flows. For electricity withdrawn from the grid, we used a price of $0.29 € / \mathrm{kWh}$ according to the average price of electricity for private consumers in Germany [73]. The feed-in

Table 4 Selected PV models

\begin{tabular}{lllll}
\hline Installed capacity $\left(\mathrm{kW}_{\mathrm{p}}\right)$ & Brand & Number of panels & Price (incl. installation and wiring; VAT) & Covered roof area $\left(\mathrm{m}_{2}\right)$ \\
\hline 4.88 & Viessmann & 16 & $5699.84 €$ & 26.08 \\
7.32 & Viessmann & 24 & $8549.76 €$ & 39.12 \\
9.76 & Viessmann & 32 & $11,399.68 €$ & 52.16 \\
\hline
\end{tabular}


remuneration for private households with a PV system up to $10 \mathrm{~kW}_{\mathrm{p}}$ is guaranteed by law and amounts to 0.12 $€ / \mathrm{kWh}$ [55]. A combination of feeding-in and withdrawing electricity with the mentioned prices yields the respective cash flows. Changes in the remuneration tariffs and the price for withdrawn electricity are taken into account for the scenario discussed in the "Flexible feed-in tariff" and "Case 5-electricity price inflation" sections.

The cash flows caused by financing are calculated on the basis of the financing programme of the German KfW for PV systems and battery storages. The whole system is financed with a credit period of 10 years and an interest rate of $2.5 \%$ [56]. Subsidies provided by the Federal Government of Germany support the repayment of the loan depending on the size of the installed system [57]. Since this type of financing is a condition for the federal repayment subsidies, which reduce the financial burden on the prosumer, the payment structure resulting from financing must be considered.

\section{Results and discussions}

\section{Baseline scenario with German market conditions}

In this chapter, we present the main results of our calculations based on data presented in previous chapters as input for parameters (baseline scenario). As described before, we look for the best constellation of PV and BES from a financial point of view for private households with 1 to 4 persons. Our results for all possible constellations are shown in the following figures. For every household size and every considered PV system ("Basis" stands for no PV system and hence no battery storage system installed), the annuity depending on the used battery size is shown in Fig. 6 .

The first insight that can be gained from our results is that the benefits of the individual constellations are very similar across all household sizes. As for the size of the PV system to be selected, the following can be stated: Regardless of all other sizes, a larger PV system is always financially more advantageous than a smaller system. Consequently, the first decision rule can already be derived for private consumers: If roof area is available, then this area should be used as much as possible for the installation of as many PV panels as possible. The only restriction is the legal cap of $10 \mathrm{~kW}_{\mathrm{p}}$ for unlimited remuneration for electricity fed into the grid. Looking not only at PV systems but also at the financial impact of the use of battery storage systems, the results are also clear. According to our calculations, the use of battery storage in all constellations impairs the financial result for the decision-maker. This is irrespective of the household size and the selected size of the PV system. Hence, the financially best alternative is always not to use any battery storage system.
From these findings, the financially optimal decision can be formulated as a simple rule. For all four household sizes, the constellation of no battery storage system and a $9.76 \mathrm{~kW}_{\mathrm{p}}$ PV system represents the financial optimum. For a 4-person household we calculated an annuity of $-828.44 €$ with this constellation. If this kind of PV system cannot be completely installed due to external circumstances, any PV system size without a battery storage system is financially more advantageous than the scenario "Basis", where all of the electricity required is drawn from the grid and which leads to an annuity of $-1323.84 €$ for a 4-person household. Therefore, potential savings of $-495.40 €$ per year can be achieved for this household size.

As mentioned above, any use of battery storage systems reduces the NPV and the related annuity of the total investment. For a one-person household, even with a $6 \mathrm{kWh}$ battery storage system, the annuity is worse than the "Basis" scenario, regardless of the selected size of the PV system. We calculated an annuity of $-511.97 €$ for the "Basis" scenario and -622.19 $€$ for a $6 \mathrm{kWh}$ battery storage system and a $9.76 \mathrm{~kW}_{\mathrm{p}}$ PV system. For the other household sizes, the smallest battery storage size was even better for larger PV systems than for the "Basis" scenario. However, the larger battery storage systems are not financially advantageous.

Although battery storage systems do not offer any financial advantages, they can significantly increase the self-sufficiency rate of a household. The degree of self-sufficiency indicates the share of self-produced electricity in total consumption. While this value is in the range of $40-50 \%$ when a PV system is used alone, it increases to as much as $95 \%$ in a singleperson household when the smallest battery storage $(6 \mathrm{kWh})$ is used. Even 77\% can be achieved in a 4-person household. Obviously, in the "Basis" scenario there is a self-sufficiency rate of $0 \%$. In addition to this considerable increase, it is still remarkable that a further increase in the size of the battery storage system does not result in a further significant increase in the self-sufficiency rate. The number of days on which a larger capacity of the battery storage system is fully utilised is very small. For more detailed results, please refer to Table 6 in the "Appendix" section.

\section{Baseline scenario with altered selected parameters}

As can be seen in the different capacity constellations, there are some solutions which create value from the financial perspective and others which do not. This is an important result for the transition of the German energy system and the respective incentives set by policymakers. On the one hand, we have to consider the falling feed-in tariffs. Since the first EEG energy law, the guaranteed remuneration has been lowered from 0.507 $€ / \mathrm{kWh}$ in 2004 to $0.12 € / \mathrm{kWh}$ in 2018 for small PV 

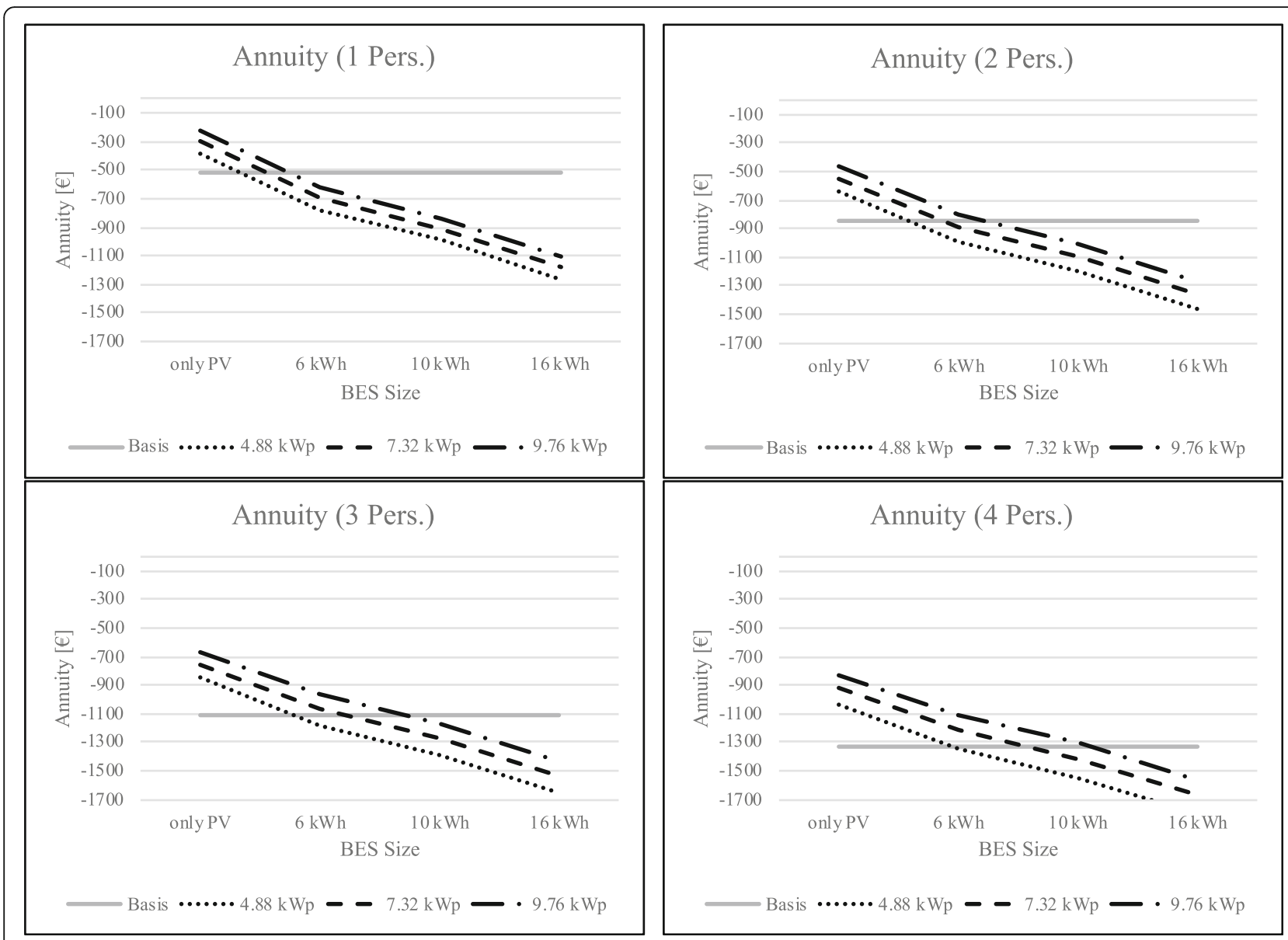

Fig. 6 Results baseline scenario

systems. A scenario discussed by politicians is the total abolition of guaranteed remuneration subsidies in the future (only relevant for newly installed PV systems). As a result, guaranteed fixed feed-in tariffs for small systems would be cancelled and even the electricity from smaller PV systems would have to be traded on national or local markets. However, even in this case, positive prices for electricity of about $0.03 € / \mathrm{kWh}$ to $0.05 € / \mathrm{kWh}$ [74] could be expected (even when opportunity revenues from self-consumption are not taken into account). On the other hand, the highest share of the investments in the given scenario is driven by the price of the BES. However, prices for chemical energy storage systems are decreasing heavily. Hence, we investigated the sensitivity to lower battery prices per kilowatt hour. The following sections discuss these variations in feed-in tariffs and the prices of battery storage systems. Table 5 presents the chosen scenarios, detailed data can be found in Tables 7 and 8 in Appendix. With the chosen household sizes, we cover over $95 \%$ of German households [75]. Furthermore, the different sizes of PV systems represent the full range of systems investigated in this paper.

\section{Flexible feed-in tariff}

As mentioned above, the guaranteed feed-in tariff in Germany was set by law to $0.507 € / \mathrm{kWh}$ for small PV systems with the first EEG energy law in 2004. The subsidies have been increasingly reduced to $0.12 € / \mathrm{kWh}$ today. In the medium-term, electrical energy produced from renewable sources will have to compete under market conditions with the current market price being about $0.04 € / \mathrm{kWh}$ on the daily market [73, 74]. Hence, we calculated scenarios where we vary different feed-in tariffs from the maximum of $0.507 € / \mathrm{kWh}$ to today's market price of $0.04 € / \mathrm{kWh}$. Considering the mentioned bandwidth, we show relative changes in attractiveness due to former developments and possible future progress. Figure 7 shows three selected scenarios with the variation of the battery storage capacity corresponding to different household sizes.

As Fig. 7 depicts, the results vary. While the horizontal lines show the annuity without any PV-BES-System, it can be seen that the German stock market price generates no added value in comparison to the consumer model ("Basis" scenario). Even with today's guaranteed 
remuneration, owning a battery only makes financial sense in a few cases with the combinations mentioned compared to the corresponding "Basis" scenario.

On the other hand, the graphs show that larger PV systems are more profitable when consumption rises. The larger batteries do not have a greater financial benefit than the smaller ones.

Not surprisingly, the financial benefit of a combined PV-BES-system is generally better with higher remuneration fees. In addition, the purchase prices for batteries are very high, which decreases the annuity of the system. As a result, the PV system (without BES) is the most profitable combination from all of the considered variations. Although batteries increase the self-sufficiency rate dramatically from $47.37 \%$ up to $88.16 \%$-according to our calculations in scenario 1 , there is no financial benefit with the current market prices of BES. However, the financial attractiveness of battery systems changes significantly if the feed-in tariffs exceed a critical value. For small households, this is the case at just under $0.40 € / \mathrm{kWh}$ and for large households it is already the case at less than $0.20 € / \mathrm{kWh}$. With the historical feed-in tariffs of over $0.507 € / \mathrm{kWh}$, an investment in such a battery system would always make sense financially.

\section{Flexible battery price}

The prices for battery storage systems need to change if an investment in them is to have a financial advantage. Since the purchase prices for batteries have decreased dramatically in the last decade and the assumption is that this trend will continue, it is reasonable to vary the different purchase prices for batteries in the given scenarios [76].

If the price decreased from $400 € / \mathrm{kWh}$ in 2013 to a forecasted $108 € / \mathrm{kWh}$ in 2020 , the decreasing rate would be about $10 \%$ per year and kilowatt hour [76]. Hence, the benefit of the calculated PV-BES-System would increase with each year. Figure 8 provides the results for the three selected scenarios that range from a low consumption with a small PV system to a high consumption with a large PV system, showing different battery options and considering different purchase prices.

The two horizontal lines represent the "Basis" scenario (grey) without any PV system or BES and the PV-only scenario (black). Obviously, the battery price does not

Table 5 Overview of the scenarios implemented

\begin{tabular}{llll}
\hline & Scenario 1 & Scenario 2 & Scenario 3 \\
\hline Number of persons & 1 & 2 & 4 \\
Energy consumption per year $(\mathrm{kWh})$ & 1714 & 2812 & 4432 \\
Size of PV system $\left(\mathrm{kW}_{\mathrm{p}}\right)$ & 4.88 & 7.32 & 9.78 \\
\hline
\end{tabular}

influence these scenarios. The other graphs show the different battery options in the scenarios. According to our calculations, the purchase price of the battery has a huge impact on the annuity of the PV-BES-system.

In the one-person household scenario, investment in a PV system has a positive impact on the annuity ($387.24 €$ as opposed to $-511.97 €)$. However, batteries in a small system, with low consumption and generation rate, do not have a positive financial impact $(-776.95 €$ and below).

In the two-person household scenario, again it is most profitable to only invest in a PV system ($547.94 €)$. Compared to the current consumer scenario (without PV and/or BES; annuity of $-839.94 €$ ) a $10 \%$ decrease in the battery price is sufficient for the PV-BES-system to be profitable for the small battery $(6 \mathrm{kWh})$, which leads to an annuity of $-839.92 €$. However, the large battery will only be profitable (annuity of $-840.30 €$ ) if the price is decreased by about $57 \%$.

In the four-person household scenario, we can see the higher profitability of the PV-BES-system with small $(6 \mathrm{kWh}$; annuity of $-1113.96 €)$ or medium $(10 \mathrm{kWh}$; annuity of $1307.67 €)$ BES compared to the current consumer scenario, which has an annuity of $-1323.84 €$. If the purchase price is decreased by one third, the large PV-BES-system will also have an annuity of $-1307.67 €$ and become more profitable than the current consumer model.

Overall, it can be stated that an investment in a PV system is financially profitable in all scenarios compared to the "Basis" scenario. Furthermore, the profitability of the PV-BES-scenarios increases with falling battery prices. Even if a combined PV-BES-system will always increase the autarchy of the prosumer, no scenario with BES proves to be more profitable than the PV-only system-even if battery prices decrease by up to $57 \%$. One explanation for this is the high purchase price for BES. On the other hand, the small units and small margins of electrical energy do not compensate the BES investment. This result is also driven by the fact that the full range of the battery is only used for a few days a year.

Finally, the battery price has a huge impact on the annuity of the system and can make the difference as to whether it is profitable or not. Assuming falling battery prices, some scenarios will become more profitable than others. However, if there is no focus on autarchy, investing only in PV panels without installing a battery the most profitable investment in all considered scenarios. This could change if the BES is used more flexibly, e.g. by adding a heating pump or a smart charging wall box for EVs to the system. With an increasing use of storage, its value will increase potentially. 


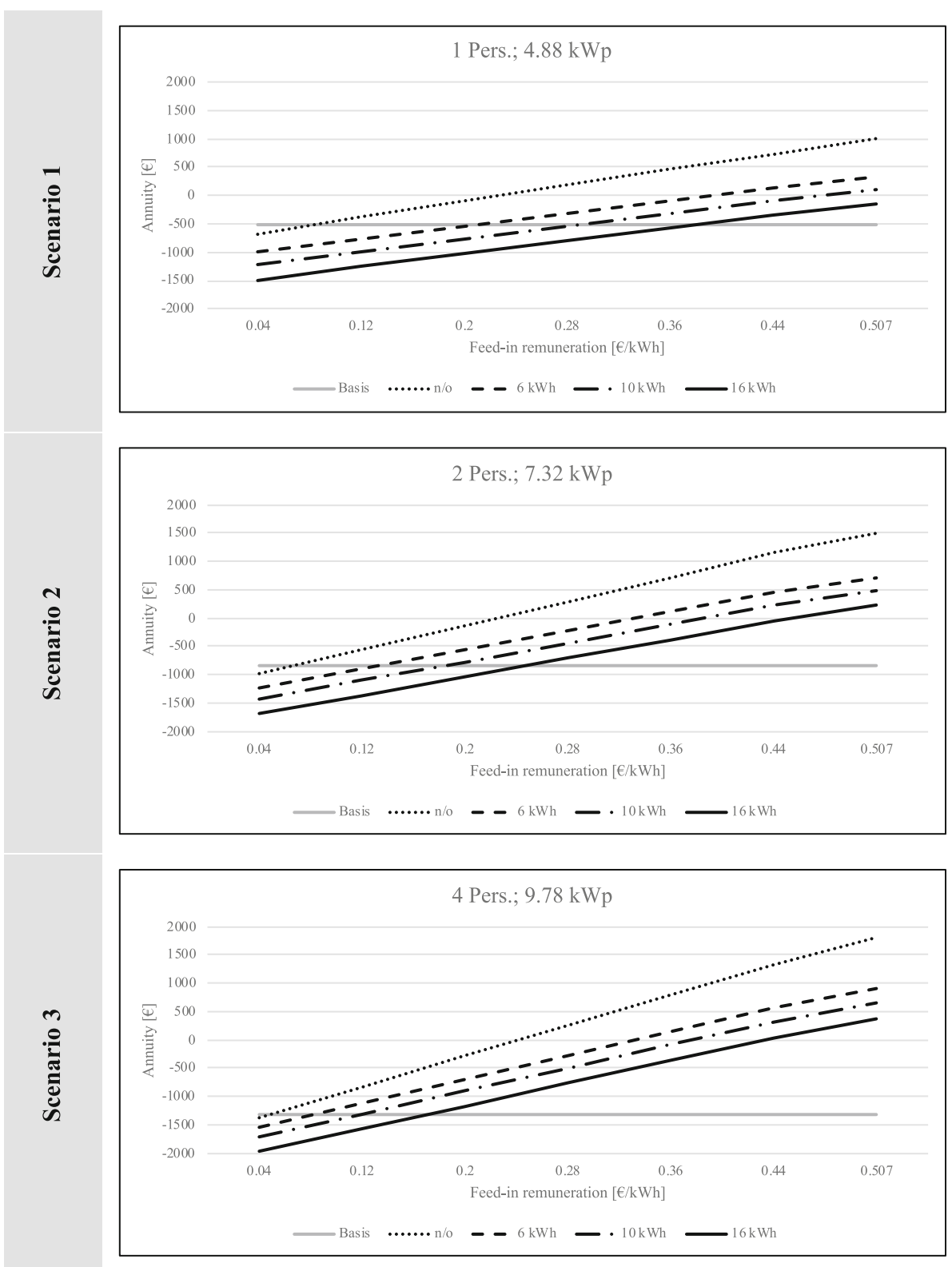

Fig. 7 Results flexible feed-in tariff

\section{Sensitivity analysis}

As described in the "Methods" section, our calculations are based on a large number of input variables, all of which have an influence on the results. Some figures are subject to different uncertainties which cannot yet be completely eliminated. In order to estimate and assess the impact of these uncertainties, we have conducted various sensitivity analyses. Having examined the influence of changes in feed-in tariffs and the prices for battery storage systems in the previous chapter, we outline below the energy efficiency of households, efficiency losses of the PV system, capacity losses of the battery storage system, internal discount rates and developments in the price of electricity withdrawn from the grid. We have chosen the same three scenarios as in the previous subchapter (see Table 5) to be compared with their corresponding "Basis" scenarios in order to create a meaningful overview. Figure 9 presents the observed scenarios, detailed data can be found in Tables 9, 10, 11 and 12 in Appendix.

\section{Case 1-energy efficiency of domestic households}

In our calculations we assumed that the electricity consumption of the various household sizes will not change over time. So far, improvements in the energy efficiency of individual appliances and the increasing number and size of appliances 


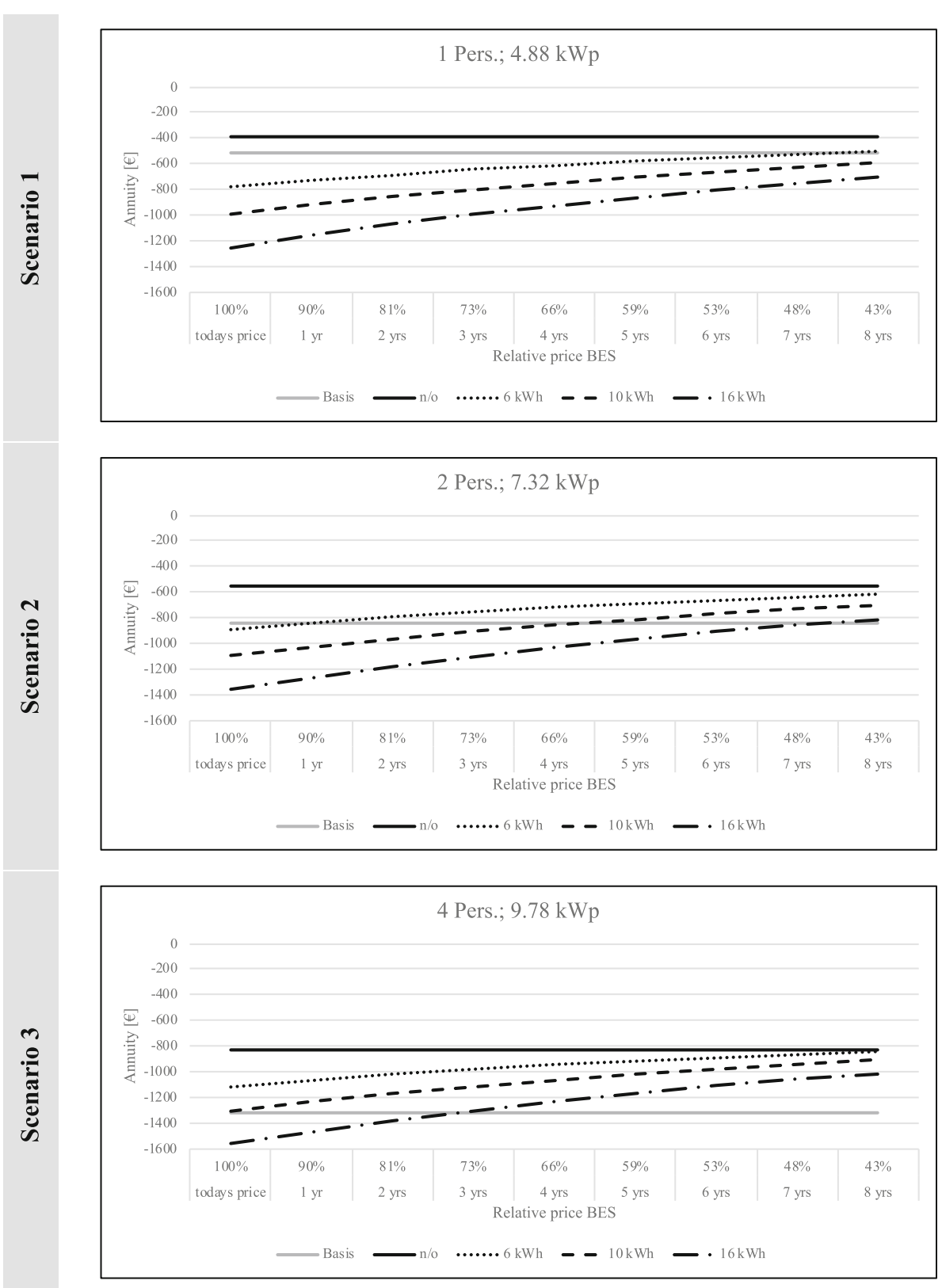

Fig. 8 Results flexible battery price

consuming electricity in private households have largely offset each other. Nevertheless, in order to carry out a comprehensive review, we examined annual savings in electricity consumption of up to $3 \%$ in our sensitivity analysis in order to meet the requirements of the EU commission [77].

As a result, an increasing annual saving in electricity consumption influences the NPV and the annuity in such a way that both of them increase. However, the corresponding graphs show that the impact is small and, above all, that there are hardly any differences between the selected scenarios and the corresponding "Basis" scenarios.
For example, for a household with one person, an increase in the annual efficiency of 3\% leads to an improvement of $21.7 \%$ in the annuity of the "Basis" scenario, while the annuity of the reference scenario $\left(4.88 \mathrm{~kW}_{\mathrm{p}}\right.$; no BES) improves by $21.5 \%$. Therefore, a significant influence of this input variable on the financial advantage of individual constellations is not given.

\section{Case 2-efficiency losses of the PV system}

In our calculations we assumed that the capacity of the installed PV system is completely available over 


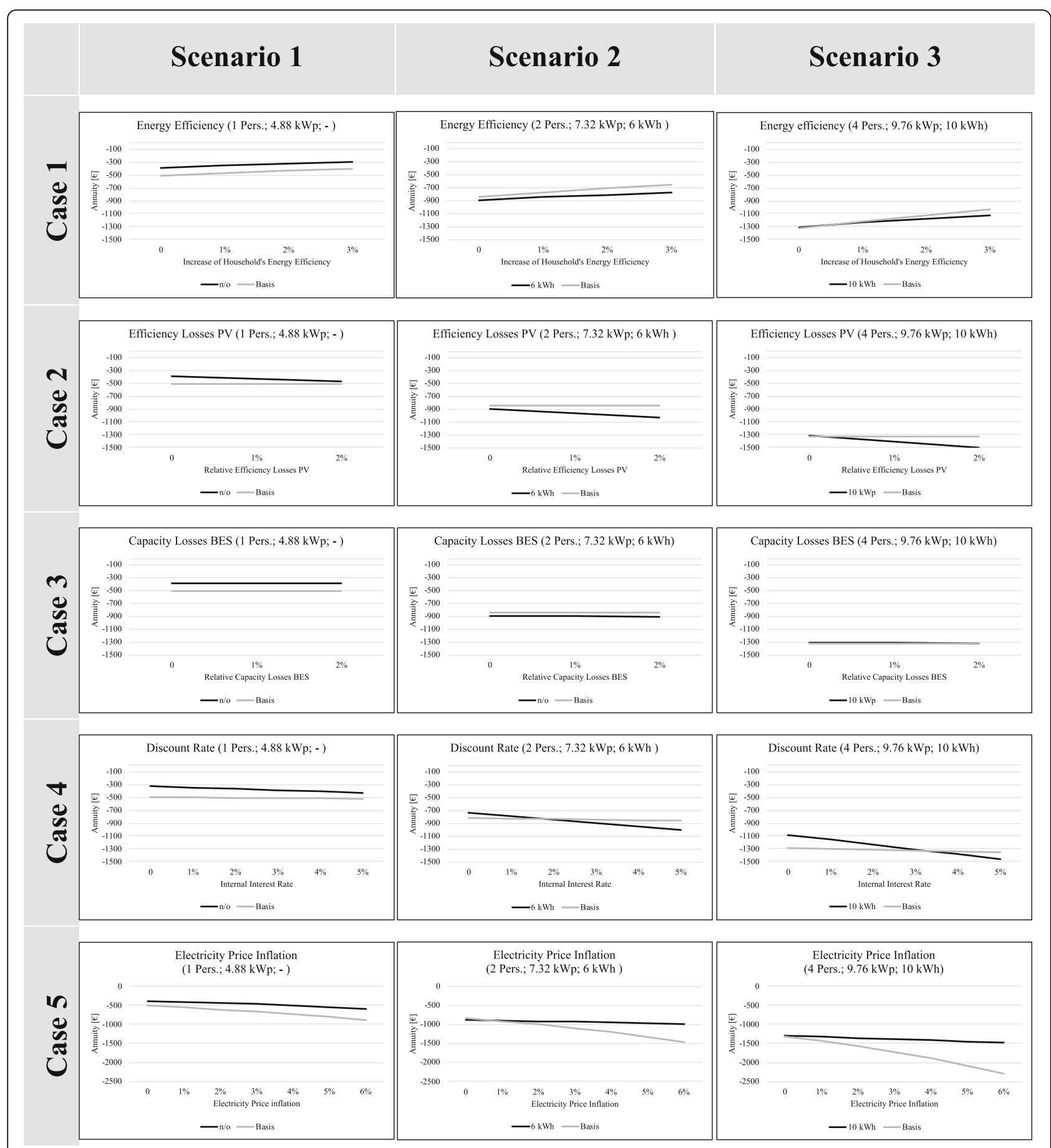

Fig. 9 Results sensitivity analyses

the entire period under consideration. This assumption can also be challenged or must be validated to the extent that the effects of a deterioration in installed capacity on the overall results are examined in a sensitivity analysis. We consider annual losses of up to $2 \%$ in the available capacity of the PV system [78].
Obviously, the result in the "Basis" scenario is not affected. However, the NPVs and the respective annuities of the reference scenarios fall due to the increasing demand for electricity drawn from the grid. For example, for a household with two persons, the annuity of the reference scenario $\left(7.32 \mathrm{~kW}_{\mathrm{p}}\right.$; $6 \mathrm{kWh})$ decreases by $15.3 \%$ when considering annual 
efficiency losses of the PV system of $2 \%$ instead of $0 \%$. Nevertheless, there are no decisive shifts in the benefits in this case either.

\section{Case 3-capacity loss of the BES system}

In our calculations we assumed that the available capacity of the battery storage systems will not be reduced. Due to a lack of experience to date, reliable values for capacity losses over time are difficult to predict and the only indication is the guarantee provided by various manufacturers (e.g. [79]) that after 10 years at least $80 \%$ of the original storage capacity will still be available (compare also [44]). To get an idea of the financial impact of potential capacity losses of the BES system, we examined the effects of an annual capacity loss of up to $2 \%$ in a sensitivity analysis. Over the entire 20-year period under consideration, this would correspond to a loss of $33.2 \%$ of the capacity initially available.

Consequently, this manipulation does not change the results of the "Basis" scenarios (no PV, no battery storage system). In the reference scenarios, the annuity deteriorates due to a decreasing proportion of the self-used electricity drawn from the BES system. The financial changes of our results are negligibly small. The difference of the annuity for a household with four persons amounts to only $0.4 \%$ in the relevant reference scenario $(9.78 \mathrm{~kW} ; 10 \mathrm{kWh})$. There is no influence on the financial advantage of decision alternatives.

\section{Case 4-discount rates}

Another factor that is examined with regard to its influence on the financial results of our calculations is the internal discount rate that is used in calculating the NPV for discounting the single cash flows. Depending on the private decisionmaker's wealth, financing alternatives and preferences for current and future consumption, the discount rate that is applied can vary. For the baseline model, we used a discount rate of $3 \%$, which we varied from 0 to $5 \%$. These assumptions are reasonable if we consider the current interest rates in Germany to be in line with assumptions made in other papers (see Table 2).

As all scenarios are characterised by series of payments, which are discounted in our model, all scenarios are affected by varied discount rates. In the "Basis" scenarios, the changes that occur are small. In the reference scenarios, the NPV decreases as the internal discount rate rises. When, for example, considering a household with two persons, a change in the discount rate from 3 to $0 \%$, improves the annuity by $1.9 \%$ in the "Basis" scenario, while there is an improvement of $18.1 \%$ in the reference scenario $\left(7.32 \mathrm{~kW}_{\mathrm{p}} ; 6 \mathrm{kWh}\right)$. However, within the analysed range of changes to the discount rate, there is no change to the financial advantages of decision alternatives.

\section{Case 5-electricity price inflation}

Our calculations assume that electricity prices will remain constant. Future developments of this influencing factor are subject to great uncertainties. The strong price increases in Germany over recent years were primarily due to the increasing share of renewable energies and the introduction of the EEG levy. In our sensitivity analysis, we examined annual price increases of up to $6 \%$, which is higher than the literature assumes (see Table 2).

Electricity price increases have a particularly strong influence on the "Basis" scenarios, but it should be noted that an annual increase of $3.53 \%$ would lead to a doubling during our observation period. Since the electricity prices for private consumers have been constant over the last 4 years [80, 81], we also took this fact into account in our case. In this respect, there are no shifts in the financial advantage. For example, comparing inflation rates for electricity prices of $0 \%$ and of 3\% shows that for a household of four persons, the annuity of the "Basis" scenario decreases by $30.5 \%$, whereas the annuity of the reference scenario $\left(9.78 \mathrm{~kW}_{\mathrm{p}} ; 10 \mathrm{kWh}\right)$ decreases by only $5.7 \%$.

The results show that the access to a BES system can minimise the risks of increasing prices for electricity. Even in the case of a $6 \%$ price inflation, the overall annuity for all scenarios only diminishes slightly (Table 13 in Appendix).

\section{Conclusions and policy implications}

In this paper, we analysed investments in PV panels and BES systems under the current economic conditions and policy from a financial prosumer perspective. In particular, we focused on the situation in Germany with its specific market characteristics. The respective model of the prosumer allowed for investments in PV panels and BES systems in different capacity combinations. Our findings provide some clear guidelines for potential investors: Regardless of the size of the household, a PV system of any size will always create a positive financial added value compared to the "Basis" scenario (consumer model). Nevertheless, the larger the system, the more advantageous it is for the owner, whereas adding a battery storage system will not create a financial advantage in every scenario compared to the "Basis" scenario. This outcome is different to the information that some suppliers provide to potential customers [82, 83]. For example, the calculations often include the full electricity price for self-consumption but neglect lost remunerations for fed-in electricity. This omission leads to too favourable economic results for additional storage capacity. 
Such simplified calculations and the frequently observed non-economic factors can explain how investors are misled when they consider the economic consequences of their decisions. Shortcomings can also result from psychological and cognitive limitations [84, 85] and an often incomplete information base [86]. In order to compensate for these shortcomings, people use so-called heuristics when making their decisions. Bazermann and Moore (2009) [87] list a total of 21 heuristics used in decision making. A lot of these can be applied to the decision situation at hand with the consequence of a suboptimal economic decision. For example, biassed decision-makers can use confirmation heuristics $[88,89]$ to include selective data in their decisions that confirm their existing attitude. Loss aversion, which leads decision-makers to perceive risks related to gains and losses differently, could also be relevant [90]. Together with varying future and present preferences, individual decision-makers can thus come to very different assessments of investment opportunities, which cannot be purely explained by economic factors.

Even though the main focus of this paper is not the prosumer's self-sufficiency rate, it should be mentioned that the autarchy of the prosumer increases dramatically with the added BES. Furthermore, the self-sufficiency rate becomes higher with a larger battery capacity, but those increases are relatively small. The low correlation of financial efficiency and the self-sufficient rate is based, on the one hand, on the fact that a battery storage system only creates financial added value in the amount of the difference between the costs for electricity from the grid and the remuneration for fed-in electricity. On the other hand, the amount of self-generated electricity which is stored for one's own subsequent use is relatively small and can hardly be increased by larger battery sizes. Thus, the high purchase prices for batteries cannot be justified from the prosumer's point of view. This result points to possibly misallocated incentives for the prosumer model.

If there is a political will to increase the number of privately installed $\mathrm{BES}$, then it is clear that the incentives need to be reconsidered. With an increasing share of RES, storage systems will be needed more and more to cover volatilities. Subsidies and remuneration systems for BES could be interlinked to the willingness of the owner to provide access to the storage system for stabilisation activities. With increasing numbers of smart charging options and a rising demand for electricity, local storage systems cannot only help to improve the self-sufficiency rate but also to help stabilise the grid.

In addition to the lack of a large-scale market structure for the prosumer model, some required equipment, such as a BES, is still expensive. In this paper, we investigated a wide range of possible scenarios which help to make the business model of a prosumer profitable and identified critical aspects that future market structures should consider if the investment by prosumers in BES systems is to become more attractive. The paper also shows that the required load for private prosumers is too small (depending on the size of the PV system). As already mentioned, political incentives could subsidise the installation of a BES system in a different way. Indeed, energy transition can proceed to the next step if an additional load, such as electric vehicles or combined heat pumps, is implemented into the system.

Another development which could increase the financial attractiveness of a BES is the use of so-called ancillary services. The storage capacities of numerous prosumers can be bundled by an aggregator who offers ancillary services for frequency and voltage control to system operators. As these services get remunerated, there is the opportunity of extra payment without additional or only low-cost investment. As services can potentially increase the efficiency of the energy system, it would be reasonable to create corresponding policy measures which support such a development.

As with every study, our work also has its limitations: Foremost, our work is based on data for the German market. As already mentioned, however, the applied model can easily be adapted to changes, since the basic problem structure remains the same. Future research can be carried out to investigate which changes and extensions can make investments in a BES profitable in the private sector. At this point we should mention the sector coupling with the aforementioned integration of electric vehicles or combined heating pumps. Furthermore, it should be evaluated to which extent a largely energy self-sufficient household can be a financial advantage. In addition, other, larger forms of private electricity generation such as biomass or small wind turbines could be considered. Integrating a financial evaluation of non-financial aspects such as autarchy could also be of interest. While our study covers solely financial aspects, an economic welfare effect is likely due to the intangible resource of self-sufficiency [91, 92] which is not represented by the considered cash flows. Quantifying this welfare could explain why people already invest in BES despite our clear findings. In summary, the current incentives for prosumers promote investments in PV panels but not in electricity storage. If it is of political interest to increase the number of BES, then politicians still have to come up with appropriate solutions. A better interplay of locally generated electricity from different renewable sources would increase the proportion of renewably generated energy in households and would also promote the further decentralisation of the electricity market. In this vein, taking external costs and societal factors into account to develop a TCO model from a societal perspective could be an avenue worth researching in the future. 


\section{Appendix}

Table 6 Results

\begin{tabular}{|c|c|c|c|c|c|c|c|c|c|c|c|}
\hline & & \multicolumn{10}{|c|}{ Size of PV system $\left(k W_{p}\right)$} \\
\hline & & \multirow{2}{*}{$\begin{array}{l}\text { No PV } \\
\text { Annuity }\end{array}$} & \multicolumn{3}{|c|}{4.88} & \multicolumn{3}{|l|}{7.32} & \multicolumn{3}{|l|}{9.76} \\
\hline & & & Battery & Annuity & Self-sufficiency & Battery & Annuity & Self-sufficiency & Battery & Annuity & Self-sufficiency \\
\hline \multirow[t]{16}{*}{ Household size } & \multirow{4}{*}{$\begin{array}{l}1 \text { person } \\
1714 \\
\text { kWh }\end{array}$} & \multirow[t]{4}{*}{-511.97} & 0 & -387.24 & $47.37 \%$ & 0 & -302.07 & $49.58 \%$ & 0 & -219.71 & $50.83 \%$ \\
\hline & & & 6 & -776.95 & $86.20 \%$ & 6 & -695.09 & $91.54 \%$ & 6 & -622.19 & $94.80 \%$ \\
\hline & & & 10 & -992.72 & $87.36 \%$ & 10 & -909.5 & $92.61 \%$ & 10 & -836.6 & $95.83 \%$ \\
\hline & & & 16 & -1258.86 & $88.16 \%$ & 16 & -1174.8 & $93.31 \%$ & 16 & -1102.14 & $96.53 \%$ \\
\hline & \multirow{4}{*}{$\begin{array}{l}2 \text { persons } \\
2812 \\
\text { kWh }\end{array}$} & \multirow[t]{4}{*}{-839.94} & 0 & -640.39 & $43.82 \%$ & 0 & -547.94 & $46.79 \%$ & 0 & -461.07 & $48.54 \%$ \\
\hline & & & 6 & -988.44 & $75.86 \%$ & 6 & -887.97 & $82.84 \%$ & 6 & -802.93 & $86.85 \%$ \\
\hline & & & 10 & -1200.98 & $77.35 \%$ & 10 & -1098.79 & $84.79 \%$ & 10 & -1011.34 & $88.96 \%$ \\
\hline & & & 16 & -1465.53 & $77.84 \%$ & 16 & -1362.6 & $85.67 \%$ & 16 & -1274.04 & $90.28 \%$ \\
\hline & \multirow{4}{*}{$\begin{array}{l}3 \text { persons } \\
3704 \\
\text { kWh }\end{array}$} & \multirow{4}{*}{-1106.38} & 0 & 852.65 & $41.40 \%$ & 0 & -752.98 & $44.84 \%$ & 0 & -661.92 & $46.87 \%$ \\
\hline & & & 6 & -1177.93 & $69.03 \%$ & 6 & -1062.26 & $76.69 \%$ & 6 & -968.14 & $81.18 \%$ \\
\hline & & & 10 & -1387.15 & $70.63 \%$ & 10 & -1268.25 & $79.17 \%$ & 10 & -1169.87 & $84.08 \%$ \\
\hline & & & 16 & -1649.99 & $71.45 \%$ & 16 & -1529.78 & $80.29 \%$ & 16 & -1430.33 & $85.43 \%$ \\
\hline & \multirow{4}{*}{$\begin{array}{l}4 \text { persons } \\
4432 \\
\text { kWh }\end{array}$} & \multirow[t]{4}{*}{-1323.84} & 0 & -1029.69 & $39.67 \%$ & 0 & -923.41 & $43.41 \%$ & 0 & -828.44 & $45.64 \%$ \\
\hline & & & 6 & -1341.68 & $64.45 \%$ & 6 & -1215.03 & $72.41 \%$ & 6 & -1113.96 & $76.93 \%$ \\
\hline & & & 10 & -1545.62 & $66.22 \%$ & 10 & -1415.1 & $75.08 \%$ & 10 & -1307.67 & $80.46 \%$ \\
\hline & & & 16 & -1805.95 & $67.44 \%$ & 16 & -1674.87 & $76.24 \%$ & 16 & -1565.92 & $81.81 \%$ \\
\hline
\end{tabular}

Table 7 Results changed selected parameters - feed-in tariff

\begin{tabular}{|c|c|c|c|c|c|c|c|}
\hline Feed-in tariff $(€)$ & 0.04 & 0.12 & 0.2 & 0.28 & 0.36 & 0.44 & 0.507 \\
\hline 1 Pers.; 4.88 kWp; n/o & -675.04 & -387.24 & -99.44 & 188.36 & 476.17 & 736.97 & 1005 \\
\hline 1 Pers.; 4.88 kW $; 6$ kWh & -1005.8 & -776.95 & -548.1 & -319.25 & -90.4 & 138.45 & 330.11 \\
\hline 1 Pers.; 4.88 kW p; 10 kWh & -1220.42 & -992.72 & -765.03 & -537.33 & -309.63 & -81.94 & 108.76 \\
\hline 1 Pers.; 4.88 kW ; 16 kWh & -1485.9 & -1258.86 & -1031.82 & -804.78 & -577.73 & -350.69 & -160.55 \\
\hline 1 Pers.; basis & -511.97 & -511.97 & -511.97 & -511.97 & -511.97 & -511.97 & -511.97 \\
\hline 2 Pers.; 7.32 kW ; - & -971.48 & -547.94 & -124.41 & 299.13 & 722.67 & 1146.2 & 1500.91 \\
\hline 2 Pers.; 7.32 kWp; 6 kWh & -1220.87 & -887.97 & -555.08 & -222.19 & 110.7 & 443.59 & 722.39 \\
\hline 2 Pers.; 7.32 kWp; 10 kWh & -1428.23 & -1098.79 & -769.34 & -439.9 & -110.45 & 218.99 & 494.91 \\
\hline 2 Pers.; 7.32 kWp; 16 kWh & -1690.43 & -1362.6 & -1034.78 & -706.95 & -379.12 & -51.29 & 223.26 \\
\hline 2 Pers.; basis & -839.94 & -839.94 & -839.94 & -839.94 & -839.94 & -839.94 & -839.94 \\
\hline 4 Pers.; 9.78 kW ; - & -1370.72 & -828.44 & -286.17 & 256.1 & 798.37 & 1340.64 & 1794.79 \\
\hline 4 Pers.; 9.78 kW $; 6$ kWh & -1531.85 & -1113.96 & -696.06 & -278.16 & 139.73 & 557.63 & 907.61 \\
\hline 4 Pers.; 9.78 kWp; 10 kWh & -1714.17 & -1307.67 & -901.17 & -494.68 & -88.18 & 318.32 & 658.76 \\
\hline 4 Pers.; 9.78 kW p; 16 kWh & -1968.25 & -1565.92 & -1163.59 & -761.25 & -358.92 & 43.42 & 380.37 \\
\hline 4 Pers.; basis & -1323.84 & -1323.84 & -1323.84 & -1323.84 & -1323.84 & -1323.84 & -1323.84 \\
\hline
\end{tabular}


Table 8 Results changed selected parameters-battery price

\begin{tabular}{|c|c|c|c|c|c|c|c|c|c|}
\hline \multirow[t]{2}{*}{ Battery price } & Today's price & 1 year & 2 years & 3 years & 4 years & 5 years & 6 years & 7 years & 8 years \\
\hline & $100 \%$ & $90 \%$ & $81 \%$ & $73 \%$ & $66 \%$ & $59 \%$ & $53 \%$ & $48 \%$ & $43 \%$ \\
\hline 1 Pers.; 4.88 kW $;$ n/o & -387.24 & -387.24 & -387.24 & -387.24 & -387.24 & -387.24 & -387.24 & -387.24 & -387.24 \\
\hline 1 Pers.; 4.88 kW $; 6$ kWh & -776.95 & -728.89 & -685.64 & -646.7 & -611.7 & -580.19 & -551.79 & -526.29 & -503.3 \\
\hline 1 Pers.; 4.88 kW ; 10 kWh & -992.72 & -922.82 & -859.91 & -803.28 & -752.33 & -706.51 & -665.22 & -628.09 & -594.66 \\
\hline 1 Pers.; 4.88 kW ; 16 kWh & -1258.86 & -1162.2 & -1075.2 & -996.95 & -926.44 & -863.04 & -805.97 & -754.58 & -708.38 \\
\hline 1 Pers.; basis & -511.97 & -511.97 & -511.97 & -511.97 & -511.97 & -511.97 & -511.97 & -511.97 & -511.97 \\
\hline 2 Pers.; 7.32 kW pi & -547.94 & -547.94 & -547.94 & -547.94 & -547.94 & -547.94 & -547.94 & -547.94 & -547.94 \\
\hline 2 Pers.; 7.32 kW ; 6 kWh & -887.97 & -839.92 & -796.67 & -757.73 & -722.72 & -691.21 & -662.81 & -637.31 & -614.32 \\
\hline 2 Pers.; 7.32 kW $; 10$ kWh & -1098.79 & -1028.89 & -965.97 & -909.34 & -858.39 & -812.57 & -771.29 & -734.15 & -700.73 \\
\hline 2 Pers.; 7.32 kW pi 16 kWh & -1362.6 & -1265.94 & -1178.95 & -1100.69 & -1030.19 & -966.79 & -909.72 & -858.33 & -812.13 \\
\hline 2 Pers.; basis & -839.94 & -839.94 & -839.94 & -839.94 & -839.94 & -839.94 & -839.94 & -839.94 & -839.94 \\
\hline 4 Pers.; 9.78 kWpi - & -828.44 & -828.44 & -828.44 & -828.44 & -828.44 & -828.44 & -828.44 & -828.44 & -828.44 \\
\hline 4 Pers.; 9.78 kWp; 6 kWh & -1113.96 & -1065.9 & -1022.65 & -983.71 & -948.7 & -917.19 & -888.8 & -863.29 & -840.3 \\
\hline 4 Pers.; 9.78 kW $; 10$ kWh & -1307.67 & -1237.77 & -1174.87 & -1118.25 & -1067.3 & -1021.45 & -980.16 & -943.02 & -909.59 \\
\hline 4 Pers.; 9.78 kWp; 16 kWh & -1565.92 & -1469.26 & -1382.26 & -1304.01 & -1233.5 & -1170.1 & -1113.03 & -1061.65 & -1015.44 \\
\hline 4 Pers.; basis & -1323.84 & -1323.84 & -1323.84 & -1323.84 & -1323.84 & -1323.84 & -1323.84 & -1323.84 & -1323.84 \\
\hline
\end{tabular}

Table 9 Results sensitivity analysis_energy efficiency improvement

\begin{tabular}{lllll}
\hline Energy efficiency improvement (per year) & $0 \%$ & $1 \%$ & $2 \%$ & $3 \%$ \\
\hline 1 Pers.; $4.88 \mathrm{~kW}_{\text {p; }} \mathrm{n} / \mathrm{o}$ & -387.24 & $-356.17(8.0 \%)$ & $-328.62(15.1 \%)$ & $-304.15(21.5 \%)$ \\
1 Pers.; basis & -511.97 & $-470.72(8.1 \%)$ & $-433.85(15.3 \%)$ & $-400.86(21.7 \%)$ \\
2 Pers.; $7.32 \mathrm{~kW}_{\text {p; }} 6 \mathrm{kWh}$ & -887.97 & $-846.32(4.7 \%)$ & $-810.31(8.7 \%)$ & $-779.17(12.3 \%)$ \\
2 Pers.; basis & -839.94 & $-772.26(8.1 \%)$ & $-711.77(15.3 \%)$ & $-657.65(21.7 \%)$ \\
4 Pers.; $9.78 \mathrm{~kW}_{\text {p; }}$ 10 kWh & -1307.67 & $-1239.7(5.2 \%)$ & $-1180.89(9.7 \%)$ & $-1129.97(13.6 \%)$ \\
4 Pers.; basis & -1323.84 & $-1217.16(8.1 \%)$ & $-1121.83(15.3 \%)$ & $-1036.52(21.7 \%)$ \\
\hline
\end{tabular}

Table 10 Results sensitivity analysis-efficiency losses PV

\begin{tabular}{llll}
\hline Efficiency losses PV (per year) & $0 \%$ & $1 \%$ & $2 \%$ \\
\hline 1 Pers.; $4.88 \mathrm{~kW}_{\text {pi }} \mathrm{n} / \mathrm{O}$ & -387.24 & $-431.88(-11.5 \%)$ & $-472.04(-21.9 \%)$ \\
1 Pers.; basis & -511.97 & $-511.97(0.0 \%)$ & $-511.97(0.0 \%)$ \\
2 Pers.; $7.32 \mathrm{~kW}_{\text {p; }}$ 6 kWh & -887.97 & $-959.13(-8.0 \%)$ & $-1024.07(-15.3 \%)$ \\
2 Pers.; basis & -839.94 & $-839.94(0.0 \%)$ & $-839.94(0.0 \%)$ \\
4 Pers.; $9.78 \mathrm{~kW}_{\text {p; }}$ 10 kWh & -1307.67 & $-1405.49(-7.5 \%)$ & $-1494.85(-14.3 \%)$ \\
4 Pers.; basis & -1323.84 & $-1323.84(0.0 \%)$ & $-1323.84(0.0 \%)$ \\
\hline
\end{tabular}


Table 11 Results sensitivity analysis — capacity losses BES

\begin{tabular}{llll}
\hline Capacity losses BES (per year) & $0 \%$ & $1 \%$ & $2 \%$ \\
\hline 1 Pers.; $4.88 \mathrm{~kW}_{\text {p; }} \mathrm{n} / \mathrm{O}$ & -387.24 & $-387.24(0.0 \%)$ & $-387.24(0.0 \%)$ \\
1 Pers.; basis & -511.97 & $-511.97(0.0 \%)$ & $-511.97(0.0 \%)$ \\
2 Pers.; $7.32 \mathrm{~kW}_{\text {p; }} 6 \mathrm{kWh}$ & -887.97 & $-890(-0.2 \%)$ & $-893.05(-0.6 \%)$ \\
2 Pers.; basis & -839.94 & $-839.94(0.0 \%)$ & $-839.94(0.0 \%)$ \\
4 Pers.; $9.78 \mathrm{~kW}_{\text {p; }} 10 \mathrm{kWh}$ & -1307.67 & $-1310.1(-0.2 \%)$ & $-1313.38(-0.4 \%)$ \\
4 Pers.; basis & -1323.84 & $-1323.84(0.0 \%)$ & $-1323.84(0.0 \%)$ \\
\hline
\end{tabular}

Table 12 Results sensitivity analysis_-discount rate

\begin{tabular}{|c|c|c|c|c|c|c|}
\hline Discount rate & $0 \%$ & $1 \%$ & $2 \%$ & $3 \%$ & $4 \%$ & $5 \%$ \\
\hline 1 Pers.; 4.88 kW p; n/o & $-328.84(15.1 \%)$ & $-348.25(10.1 \%)$ & $-367.75(5.0 \%)$ & -387.24 & $-406.67(-5.0 \%)$ & $-425.95(-10.0 \%)$ \\
\hline 1 Pers.; basis & $-497.06(2.9 \%)$ & $-502.03(1.9 \%)$ & $-507(1.0 \%)$ & -511.97 & $-516.94(-1.0 \%)$ & $-521.91(-1.9 \%)$ \\
\hline 2 Pers.; 7.32 kW ; 6 kWh & $-727.19(18.1 \%)$ & $-780.63(12.1 \%)$ & $-834.3(6.0 \%)$ & -887.97 & $-941.45(-6.0 \%)$ & $-994.54(-12.0 \%)$ \\
\hline 2 Pers.; basis & $-815.48(2.9 \%)$ & $-823.36(2.0 \%)$ & $-831.79(1.0 \%)$ & -839.94 & $-848.1(-1.0 \%)$ & $-856.25(-1.9 \%)$ \\
\hline 4 Pers.; 9.78 kW $; 10$ kWh & $-1082.45(17.2 \%)$ & $-1157.3(11.5 \%)$ & $-1232.48(5.7 \%)$ & -1307.67 & $-1382.58(-5.7 \%)$ & $-1456.95(-11.4 \%)$ \\
\hline 4 Pers.; basis & $-1285.28(2.9 \%)$ & $-1298.13(1.9 \%)$ & $-1310.99(1.0 \%)$ & -1323.84 & $-1336.69(-1.0 \%)$ & $-1349.54(-1.9 \%)$ \\
\hline
\end{tabular}

Table 13 Results sensitivity analysis -inflation electricity price

\begin{tabular}{llllllll}
\hline Inflation electricity price & $0 \%$ & $1 \%$ & $2 \%$ & $3 \%$ & $4 \%$ & $5 \%$ & $6 \%$ \\
\hline 1 Pers.; 4.88 kWp; $\mathrm{n} / \mathrm{O}$ & -387.24 & -411.47 & -438.65 & -469.16 & -503.43 & -541.89 & -585.34 \\
& & $(-6.3 \%)$ & $(-13.3 \%)$ & $(-21.2 \%)$ & $(-30.0 \%)$ & $(-39.9 \%)$ & $(-51.2 \%)$ \\
1 Pers.; basis & -511.97 & -558.19 & -610.02 & -668.2 & -733.58 & -807.09 & -889.81 \\
& & $(-9.0 \%)$ & $(-19.2 \%)$ & $(-30.5 \%)$ & $(-43.3 \%)$ & $(-57.6 \%)$ & $(-73.8 \%)$ \\
2 Pers.; 7.32 kW ; 6 kWh & -887.97 & -899.89 & -913.25 & -928.24 & -945.08 & -964 & -985.28 \\
& & $(-1.3 \%)$ & $(-2.8 \%)$ & $(-4.5 \%)$ & $(-6.4 \%)$ & $(-8.6 \%)$ & $(-11 \%)$ \\
2 Pers.; basis & -839.94 & -915.77 & -1000.8 & -1096.26 & -1203.51 & -1324.12 & -1459.83 \\
& & $(-9.0 \%)$ & $(-19.2 \%)$ & $(-30.5 \%)$ & $(-43.3 \%)$ & $(-57.6 \%)$ & $(-73.8 \%)$ \\
4 Pers.; 9.78 kWp; 10 kWh & -1307.67 & -1329.68 & -1354.36 & -1382.06 & -1413.16 & -1448.13 & -1487.47 \\
& & $(-1.7 \%)$ & $(-3.6 \%)$ & $(-5.7 \%)$ & $(-8.1 \%)$ & $(-10.7 \%)$ & $(-13.7 \%)$ \\
4 Pers.; basis & -1323.84 & -1443.35 & -1577.37 & -1727.82 & -1896.86 & -2086.94 & -2300.84 \\
& & $(-9.0 \%)$ & $(-19.2 \%)$ & $(-30.5 \%)$ & $(-43.3 \%)$ & $(-57.6 \%)$ & $(-73.8 \%)$ \\
\hline
\end{tabular}




\section{Abbreviations}

$€$ : Euro; BES: Battery energy storage; $C_{\text {Capex: }}$ Capital expenditure; $C_{\text {Opex: }}$ Operational expenditure; $C_{\mathrm{TCO}_{\mathrm{p}}}$ : Annual prosumer-oriented total cost of ownership; DC: Direct current; DSO: Distribution system operator:

EEG: Erneuerbare-Energien-Gesetz (Renewable Energy Law); i: Discount rate; KfW: Kreditanstalt für Wiederaufbau; kWh: Kilowatt hour; kW: Kilowatt peak; NPV: Net present value; PV: Photovoltaic; RES: Renewable energy system; $t$ : Period; T: Period under review; TCO: Total cost of ownership; TCOp: Prosumer-oriented total cost of ownership; VAT: Value added tax; VBA: Visual basics for applications

\section{Acknowledgements}

The authors thank Julia Bogacki, Elisabeth Burkhart, Kai Klöckner and Fehmi Yüksel for helpful comments on the manuscript.

\section{Authors' contributions}

KK and PW designed the underlying model, implemented the calculations and wrote the manuscript. PL was involved in the ideas and conception. Furthermore, he revised the manuscript. All authors read and approved the final manuscript.

\section{Funding}

The work on this article has received funding from the European Union's Horizon 2020 Framework Programme for Research and Innovation under the grant agreement no 727481

\section{Availability of data and materials}

The datasets used and analysed during the current study are available from the corresponding author on reasonable request.

\section{Ethics approval and consent to participate}

Not applicable

\section{Consent for publication}

Not applicable

\section{Competing interests}

The authors declare that they have no competing interests.

\section{Received: 21 February 2019 Accepted: 27 November 2019}

Published online: 13 December 2019

\section{References}

1. Ohlhorst D (2015) Germany's energy transition policy between national targets and decentralized responsibilities. J Integr Environ Sci 12:303-322. https://doi.org/10.1080/1943815X.2015.1125373

2. Strunz S (2014) The German energy transition as a regime shift. Ecol Econ Institutional Dyn 100:150-158

3. Edwards I (2018) The role of decentralized renewable energy in peacebuilding. QUNO, Geneva

4. European Parliament (2009) Directive 2009/28/EC of the European Parliament and of the Council of 23 April 2009

5. Bundesministerium für Wirtschaft und Energie (2010) Energiekonzept für eine umweltschonende, zuverlässige und bezahlbare Energieversorgung

6. European Commission (1997) Energie für die Zukunft: Erneuerbare Energieträger

7. BDEW; AGEB; Statistisches Bundesamt (2017) Anteil der Photovoltaik an de Bruttostromerzeugung in Deutschland in den Jahren 2002 bis 2017. https://de statista.com/statistik/daten/studie/250915/umfrage/anteil-der-photovoltaik-ander-stromerzeugung-in-deutschland/. Accessed 21 Nov 2018

8. Rogelj J, Shindell D, Jiang K et al (2018) Mitigation pathways compatible with $1.5^{\circ} \mathrm{C}$ in the context of sustainable development. Glob Warm $15^{\circ} \mathrm{C} \mathrm{An}$ IPCC Spec Rep [.], p 82

9. Hake JF, Fischer W, Venghaus S, Weckenbrock C (2015) The German Energiewende - History and status quo. Energy 92:532-546. https://doi.org/ 10.1016/j.energy.2015.04.027

10. Kersting S (2018) Klimaziel für 2020: "Deutschland lässt sich gehen". Handelsblatt. http://www.handelsblatt.com/politik/deutschland/klimazieleverfehlt-deutschland-laesst-sich-gehen/20881310.html. Accessed $21 \mathrm{Nov}$ 2018
11. CDU, CSU, SPD (2018) Ein neuer Aufbruch für Europa Eine neue Dynamik für Deutschland Ein neuer Zusammenhalt für unser Land

12. Römer B, Reichhart P, Kranz J, Picot A (2012) The role of smart metering and decentralized electricity storage for smart grids: The importance of positive externalities. Energy Policy 50:486-495. https://doi.org/10.1016/j.enpol.2012. 07.047

13. Schleicher-Tappeser R (2012) How renewables will change electricity markets in the next five years. Energy Policy 48:64-75. https://doi.org/10. 1016/j.enpol.2012.04.042

14. Koirala BP, Koliou E, Friege J et al (2016) Energetic communities for community energy: a review of key issues and trends shaping integrated community energy systems. Renew Sustain Energy Rev 56:722-744. https:// doi.org/10.1016/j.rser.2015.11.080

15. Grübler A, Nakićenović N, Nordhaus WD (2002) Technological change and the environment. Resources for the Future, Washigtion, DC

16. Bundesregierung Deutschland (2000) Gesetz für den Vorrang Erneuerbarer Energien (Erneuerbare-Energien-Gesetz - EEG) sowie zur Änderung des Energiewirtschaftsgesetzes und des Mineralölsteuergesetzes vom März 2000 Bundesgesetzblatt, Germany

17. Bundesregierung Deutschland (2004) Gesetz zur Neuregelung des Rechts der Erneuerbaren Energien im Strombereich vom 21. Juli 2004. Bundesgesetzblatt, Germany

18. Train K (1985) Discount rates in consumers' energy-related decisions: a review of the literature. Energy 10:1243-1253. https://doi.org/10.1016/03605442(85)90135-5

19. Rai V, Sigrin B (2013) Diffusion of environmentally-friendly energy technologies: buy versus lease differences in residential PV markets. Environ Res Lett 8. https://doi.org/10.1088/1748-9326/8/1/014022

20. Bundesministerium für Wirtschaft und Energie (2018) Installierte Leistung (kumuliert) der Photovoltaikanlagen in Deutschland in den Jahren 2000 bis 2017 (in Megawattpeak). https://de.statista.com/statistik/daten/studie/13547/ umfrage/leistung-durch-solarstrom-in-deutschland-seit-1990/. Accessed 21 Nov 2018

21. BDEW: Bundesverband der Energie- und Wasserwirtschaft e.V. (2017) BDEWStrompreisanalyse Februar 2017

22. Bundesnetzagentur, Bundeskartellamt (2018) Bericht - Monitoringbericht 2018

23. Bergman $N$, Eyre $N$ (2011) What role for microgeneration in a shift to a low carbon domestic energy sector in the UK? Energy Effic 4:335-353. https:// doi.org/10.1007/s12053-011-9107-9

24. European Commission (2019) Energy orices and costs in Europe - report from the Commission to the European Parliament, the Council, the European Economic and Social Committee and the Committee of the Regions

25. RES Legal Europe (2019) Legal sources on renewable energy. http://www. res-legal.eu/search-by-country/. Accessed 16 Aug 2019

26. Allcott H, Mullainathan S (2010) Behavior and energy policy. Science 327: 1204-1205

27. Bager S, Mundaca L (2017) Making 'Smart Meters' smarter? Insights from a behavioural economics pilot field experiment in Copenhagen, Denmark. Energy Res Soc Sci 28:68-76. https://doi.org/10.1016/J.ERSS.2017.04.008

28. Frederiks ER, Stenner K, Hobman EV (2015) Household energy use: applying behavioural economics to understand consumer decision-making and behaviour. Renew Sustain Energy Rev 41:1385-1394. https://doi.org/10. 1016/J.RSER.2014.09.026

29. Hahn R, Metcalfe R (2016) The impact of behavioral science experiments on energy policy. Econ Energy Environ Policy 5:1-23. https://doi.org/10.5547/ 2160-5890.5.2.rhah

30. Akter MN, Mahmud MA, Oo AMT (2017) Comprehensive economic evaluations of a residential building with solar photovoltaic and battery energy storage systems: an Australian case study. Energy Build 138:332-346. https://doi.org/10.1016/j.enbuild.2016.12.065

31. Bertolini M, D'Alpaos C, Moretto M (2016) Investing in photovoltaics: riming, plant sizing and smart grid felxibility. Fondazione Eni Enrico Mattei, Padova

32. Bortolini M, Gamberi M, Graziani A (2014) Technical and economic design of photovoltaic and battery energy storage system. Energy Convers Manag 86:81-92. https://doi.org/10.1016/j.enconman.2014.04.089

33. Comello S, Reichelstein S (2016) Cost competitiveness of residential solar PV: the impact of net metering restrictions

34. Cucchiella F, D'Adamo I, Gastaldi M (2016) Photovoltaic energy systems with battery storage for residential areas: an economic analysis. J Clean Prod 131:460-474. https://doi.org/10.1016/j.jclepro.2016.04.157 
35. Kamankesh H, Agelidis VG (2017) A sufficient stochastic framework for optimal operation of micro-grids considering high penetration of renewable energy sources and electric vehicles. J Intell Fuzzy Syst 32:373-387. https:// doi.org/10.3233/JIFS-151955

36. Kaschub T, Jochem P, Fichtner W (2016) Solar energy storage in German households: profitability, load changes and flexibility. Energy Policy 98:520532. https://doi.org/10.1016/j.enpol.2016.09.017

37. Klise GT, Johnson JL, Adomatis SK (2013) Valuation of solar photovoltaic systems using a discounted cash flow approach. Appraisal J 81:316-330

38. McDowall J (2017) Living off grid - electric light \& power. https://www.elp. com/articles/powergrid_international/print/volume-22/issue-5/features/ living-off-grid.html. Accessed 23 Nov 2018

39. Naumann M, Karl RC, Truong CN et al (2015) Lithium-ion battery cost analysis in PV-household application. Energy Procedia 73:37-47. https://doi. org/10.1016/j.egypro.2015.07.555

40. Rosen C, Madlener R (2016) Regulatory options for local reserve energy markets: implications for prosumers, utilities, and other stakeholders. Energy J 37:39-50. https://doi.org/10.5547/01956574.37.SI2.cros

41. Rylatt M, Gammon R, Boait P et al (2013) Cascade: an agent based framework for modeling the dynamics of smart electricity systems. Emerg Complex Organ 15:1-13

42. Uddin K, Gough R, Radcliffe J et al (2017) Techno-economic analysis of the viability of residential photovoltaic systems using lithium-ion batteries for energy storage in the United Kingdom. Appl Energy 206:12-21. https://doi. org/10.1016/j.apenergy.2017.08.170

43. Vosoogh M, Kamyar M, Akbari A, Abbasi A (2014) A novel modification approach based on MTLBO algorithm for optimal management of renewable micro-grids in power systems. J Intell Fuzzy Syst 27:465-473. https://doi.org/10.3233/IFS-131014

44. Zhang Y, Lundblad A, Campana PE, Yan J (2016) Employing battery storage to increase photovoltaic self-sufficiency in a residential building of Sweden Yang. Energy Procedia 88:455-461. https://doi.org/10.1016/j.egypro.2016.11.284

45. Government of Canada (2019) RETScreen. https://www.nrcan.gc.ca/energy/ retscreen/7465. Accessed 19 Aug 2019

46. Ellram LM, Siferd SP (1993) Purchasing: the cornerstone of the total cost of ownership concept. J Bus Logist 14:163-184

47. Ellram LM (1995) Total cost of ownership: an analysis approach for purchasing. Int J Phys Distrib Logist Manag 25:4-23. https://doi.org/10.1108/ 09600039510099928

48. Ellram LM, Siferd SP (1998) Total cost of ownership: a key concept in strategic cost management decisions. J Bus Logist 19:55-84

49. Geissdörfer K, Gleich R, Wald A (2009) Standardisierungspotentiale lebenszyklusbasierter Modelle des strategischen Kostenmanagements. Zeitschrift für Betriebswirtschaft 79:693-715. https://doi.org/10.1007/s11573009-0256-7

50. Kaplan RS (1992) In defense of activity-based cost management. Manag Account 70:58-63

51. Bhutta KS, Huq F (2002) Supplier selection problem: a comparison of the total cost of ownership and analytic hierarchy process approaches. Supply Chain Manag An Int J 7:126-135. https://doi.org/10.1108/ 13598540210436586

52. Degraeve Z, Labro E, Roodhooft F (2000) An evaluation of vendor selection models from a total cost of ownership perspective. Eur J Oper Res 125:3458. https://doi.org/10.1016/S0377-2217(99)00199-X

53. Ellram LM (1994) A taxonomy of total cost of ownership models. J Bus Logist 15:171-191

54. Götze U, Weber T (2008) ZP-Stichwort: Total Cost of Ownership. Zeitschrift für Plan Unternehmenssteuerung 19:249-257. https://doi.org/10.1007/ s00187-008-0054-3

55. Bundesministerium für Wirtschaft und Energie (2014) Gesetz für den Ausbau erneuerbarer Energien (Erneuerbare - Energien - Gesetz - EEG 2014) Bundesgesetzblatt, Germany

56. KfW (2017) Merkblatt Erneuerbare Energien. In: 6000000178

57. KfW (2017) Handreichung zur Ermittlung des Tilgungszuschusses KfWProgramm Erneuerbare Energien - Speicher, p 275

58. SMA Solar Technology AG (2018) Solar-Wechselrichter | SMA Solar. https:// www.sma.de/produkte/solar-wechselrichter/sunny-boy-3600-5000-smartenergy.html. Accessed 21 Nov 2018

59. Daimler AG (2018) Mercedes-Benz Energy: Energiespeicher. https://www. mercedes-benz.com/de/mercedes-benz-energy/energiespeicher-homeprivatkunde/. Accessed 21 Nov 2018
60. Tesla Germany GmbH (2018) Powerwall | Tesla Heimspeicher. https://www. tesla.com/de_DE/powerwall. Accessed 21 Nov 2018

61. LG Electronics Deutschland GmbH (2018) LG ESS | LG DE Business. http:// www.lg.com/de/business/ess/ueber-lg-energiespeichersysteme. Accessed 21 Nov 2018

62. Samsung SDI CO. L (2018) Samsung SDI ESS (Energy Storage System). http://www.samsungsdi.com/ess/index.html. Accessed 21 Nov 2018

63. sonnen $\mathrm{GmbH}$ (2018) sonnenBatterie eco- der effiziente Stromspeicher | sonnen. https://www.sonnenbatterie.de/de/sonnenbatterie-0. Accessed 21 Nov 2018

64. RWTH Aachen (Institut für Stromrichtertechnik und Elektrische Antriebe) (2018) Wichtigste Hersteller von Solarstromspeichern in Deutschland nach Marktanteil im Jahr 2016. https://de.statista.com/statistik/daten/studie/5 85226/umfrage/marktanteile-der-hersteller-fuer-solarstromspeicher-indeutschland/. Accessed 23 Nov 2018

65. BSW; Statista estimates (2016) Preisentwicklung für eine fertig installierte Solaranlage in Deutschland in den Jahren 2007 bis 2015 (in Euro por Kilowattpeak). https:/de. statista.com/statistik/daten/studie/156490/umfrage/preis-fuer-eine-fertig-installiertesolaranlage-in-deutschland/. Accessed 23 Nov 2018

66. Viessmann Werke GmbH \& Co. KG (2018) Photovoltaik-Modul Vitovolt 300 für Wohngebäude | Viessmann. https://www.viessmann.de/de/ wohngebaeude/photovoltaik/photovoltaik-module/vitovolt-300.html. Accessed 21 Nov 2018

67. EurObserv'ER (2015) Wichtige Hersteller von Sonnenkollektoren in Europa nach Produktionsmenge im Jahr 2014 (in 1.000 Quadratmeter). https://de. statista.com/statistik/daten/studie/270145/umfrage/wichtige-hersteller-vonsolarkollektoren-in-europa-nach-produktionsmenge/. Accessed 23 Nov 2018

68. Bundesministerium für Wirtschaft und Energie (2017) EEG in Zahlen: Vergütungen, Differenzkosten und EEG-Umlage 2000 bis 2018

69. Regionetz GmbH (2018) Regionetz - Startseite. https://www.regionetz.de/. Accessed 21 Nov 2018

70. European Commission Joint Research Centre (2012) JRC's Directorate C, Energy, Transport and Climate - PVGIS - European Commission. http://re.jrc. ec.europa.eu/pvgis/. Accessed 21 Nov 2018

71. Renewable Energy Concepts (2018) Sonneneinstrahlung Deutschland Solarkarte in $\mathrm{KWh} / \mathrm{m}^{2}$. http://www.renewable-energy-concepts.com/ german/sonnenenergie/basiswissen-solarenergie/geografische-lage-kwhm2. html. Accessed 23 Nov 2018

72. Deutscher Wetterdienst (2018) Wetter und Klima - Deutscher Wetterdienst Leistung - Strahlung - Solarenergie. https://www.dwd.de/DE/leistungen/ solarenergie/solarenergie.html. Accessed 23 Nov 2018

73. Statistisches Bundesamt (2018) Daten zur Energiepreisentwicklung - 2018 Lange Reihen von Januar 2000 bis Januar 2018

74. EPEX SPOT (2018) Börsenstrompreis am EPEX-Spotmarkt für Deutschland/ Österreich von April 2017 bis April 2018 (in Euro pro Megawattstunde). https://de.statista.com/statistik/daten/studie/289437/umfrage/strompreis-amepex-spotmarkt/. Accessed 23 Nov 2018

75. Umweltbundesamt (2019) Bevölkerungsentwicklung und Struktur privater Haushalte. https://www.umweltbundesamt.de/daten/private-haushaltekonsum/strukturdaten-privater-haushalte/bevoelkerungsentwicklungstruktur-privater\#textpart-1. Accessed 16 Aug 2019

76. Horváth \& Partners (2016) Weltweite Preisentwicklung für Lithium-lonenBatterien von 2013 bis 2020 (in Euro/kWh). https://de.statista.com/statistik/ daten/studie/534429/umfrage/weltweite-preise-fuer-lithium-ionen-akkus/. Accessed 23 Nov 2018

77. European Commission (2011) Energy efficiency plan 2011. European Commission, Brussels

78. Christian Münch GmbH (2018) Degraduation \& Alterung der Photovoltaik Module. http://www.solaranlage.eu/photovoltaik/technik-komponenten/ solarmodule/degradation. Accessed 21 Nov 2018

79. innogy SE (2018) innogy - Speicherlösungen. https:/www.innogy.com/web/ cms/de/3824036/fuer-zuhause/energie-selbst-erzeugen/photovoltaik-aussonne-wird-strom/speicherloesungen/. Accessed 21 Nov 2018

80. Brandt M (2014) Strompreisentwicklung in Deutschland. https://de.statista. com/infografik/2108/strompreisentwicklung-in-deutschland/. Accessed 23 Nov 2018

81. BDEW: Bundesverband der Energie- und Wasserwirtschaft (2018) Strompreisentwicklung 2000 - 2018 - Entwicklung der Strompreise für Privathaushalte in Deutschland. https://1-stromvergleich.com/download/ strompreisentwicklung-2018/. Accessed 23 Nov 2018

82. sonnen $\mathrm{GmbH}$ (2019) Ihr Ersparnis mit sonnen. https://realdaten.sonnen.de/ index.html 
83. Christian Münch GmbH (2019) Solarrechner. https://www.solaranlage.eu/ solar/solarrechner. Accessed 17 Sept 2019.

84. Cyert RM, March JG (2013) A behavioral theory of the firm. Martino Fine Books, Eastford

85. Simon HA (1976) Administrative behavior: a study of decision-making processes in administrative organization. Free Press, New York

86. Lax DA, Sebenius JK (1986) The manager as negotiator. The Free Press, New York City

87. Bazerman MH, Moore DA (2009) Judgement in managerial decision making. Wiley, New Caledonia

88. Baron J, Beattie J, Hershey JC (1988) Heuristics and biases in diagnostic reasoning: II. Congruence, information, and certainty. Organ Behav Hum Decis Process 42:88-110. https://doi.org/10.1016/0749-5978(88)90021-0

89. Klayman J, Ha Y (1987) Confirmation, disconfirmation, and information in hypothesis testing. Psychol Rev 94:211-228. https://doi.org/10.1037/0033295X.94.2.211

90. Kahneman D, Tversky A (1979) Prospect theory: an analysis of decision under risk. Econometrica 47:263-291

91. Fernández E, Montes JM, Vázquez CJ (2000) Typology and strategic analysis of intangible resources. A resource-based approach. Technovation 20:81-92. https://doi.org/10.1016/S0166-4972(99)00115-7

92. Diefenbach T (2006) Intangible resources: a categorial system of knowledge and other intangible assets. J Intellect Cap 7:406-420. https://doi.org/10. $1108 / 14691930610681483$

\section{Publisher's Note}

Springer Nature remains neutral with regard to jurisdictional claims in published maps and institutional affiliations.

Ready to submit your research? Choose BMC and benefit from:

- fast, convenient online submission

- thorough peer review by experienced researchers in your field

- rapid publication on acceptance

- support for research data, including large and complex data types

- gold Open Access which fosters wider collaboration and increased citations

- maximum visibility for your research: over $100 \mathrm{M}$ website views per year

At $\mathrm{BMC}$, research is always in progress.

Learn more biomedcentral.com/submissions 